\title{
GSA
}

Photovoltaic-Thermal New

\section{Technology Demonstration}

Jesse Dean (NREL)

Peter McNutt (NREL)

Lars Lisell (NREL)

Jay Burch (NREL)

Dennis Jones (Group14)

David Heinicke (Group14) 


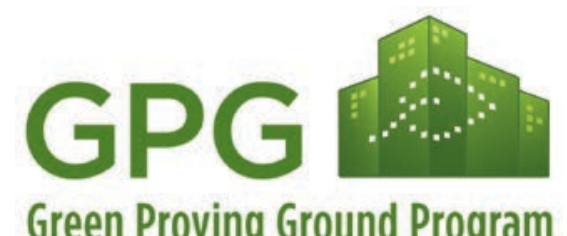

Green Proving Ground Program
The Green Proving Ground program leverages GSA's real estate portfolio to evaluate innovative sustainable building technologies and practices. Findings are used to support the development of GSA performance specifications and inform decision-making within GSA, other federal agencies, and the real estate industry. The program aims to drive innovation in environmental performance in federal buildings and help lead market transformation through deployment of new technologies. 


\section{Disclaimer}

This manuscript has been authored by employees of the Alliance for Sustainable Energy, LLC ("Alliance") under Contract No. DE-AC36-08G028308 with the U.S. Department of Energy ("DOE”).

This report was prepared as an account of work sponsored by the United States Government. Neither the United States Government nor any agency thereof, nor the authors of the report, nor any of their employees, makes any warranty, express or implied, or assumes any legal liability or responsibility for the accuracy, completeness, or usefulness of any information, apparatus, product, or process disclosed, or represents that its use would not infringe privately owned rights. Reference herein to any specific commercial product, process, or service by its trade name, trademark, manufacturer, or otherwise, does not constitute or imply its endorsement, recommendation, or favoring by the United States Government or any agency thereof, or the authors of the report. The views and opinions of authors expressed herein do not necessarily state or reflect those of the United States Government or any agency thereof.

The work described in this report was funded by the U.S. General Services Administration and the Federal Energy Management Program of the U.S. Department of Energy under Contract Nos. GSA: PX013232, NREL: IAG-11-1827.

\section{Acknowledgements}

United States General Services Administration (GSA) Region 1: Jeffrey Schetrompf, Roman Piaskoski, Sarah Wenninger, Waikit Lui, Noretta Lleshi

United States General Services Administration (GSA) Green Proving Ground program: Kevin Powell, Maria Filios, Christine Wu

Tenfold Information Design: Andrea Silvestri

For more information contact:

Kevin Powell

Program Manager

Green Proving Ground

Office of the Chief Greening Officer

U.S. General Services Administration

50 United Nations Plaza

San Francisco, CA 94102-4912

Email: kevin.powell@gsa.gov 


\section{Table of Contents}

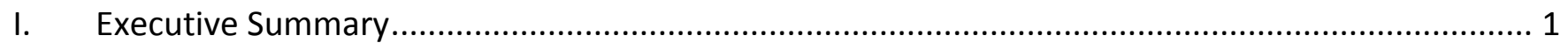

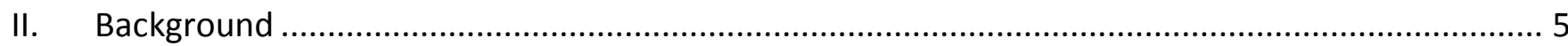

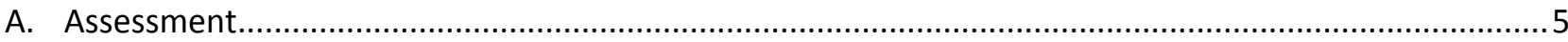

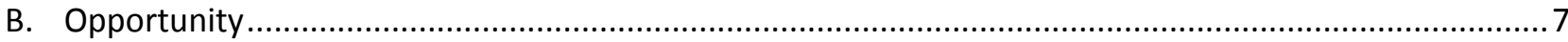

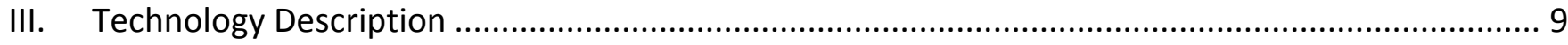

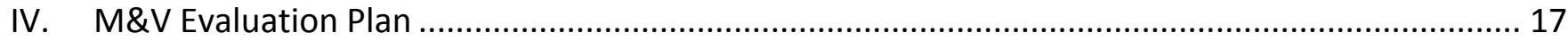

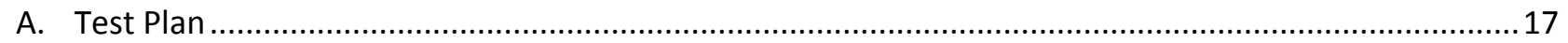

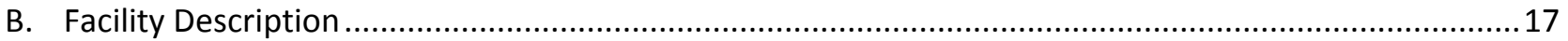

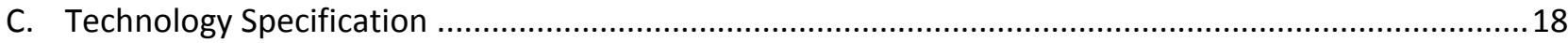

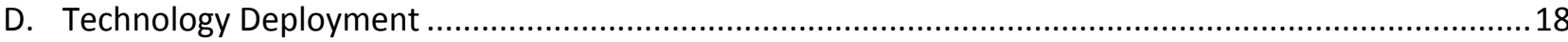

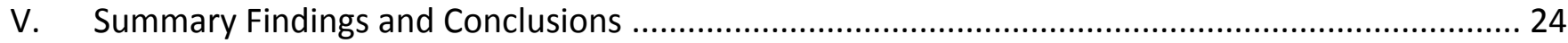

A. Overall Technology Assessment at Demonstration Facility .................................................................24

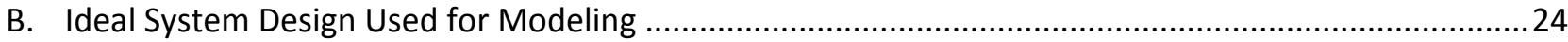

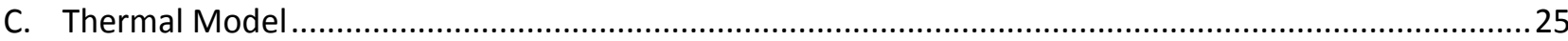

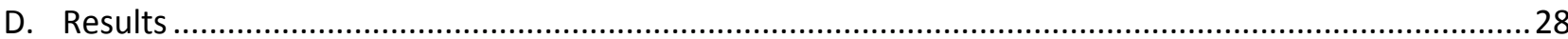

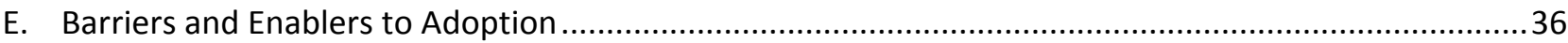

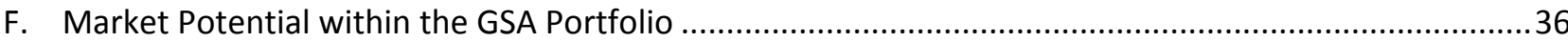

G. Recommendations for Installation, Commissioning, Training and Change Management ......................36

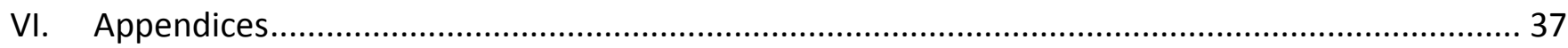

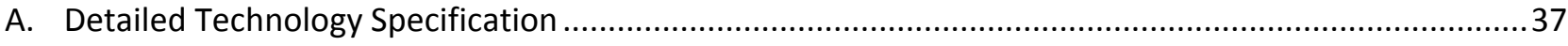

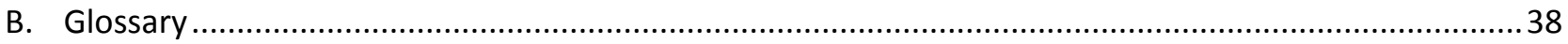




\section{Executive Summary}

\section{Background}

Integrating renewable energy (RE) systems into the built environment and using available rooftop space for solar energy installations provide a number of financial and societal benefits for the U.S. General Services Administration (GSA). These benefits include cost savings, increased energy cost security, and reduction of greenhouse gas emissions. Utilization of available rooftop area also provides an opportunity to implement solar energy technologies such as photovoltaic (PV) and solar hot water (SHW) systems to generate electricity and hot water for those buildings. Given the fact that most of the federally owned and leased facilities for which GSA is responsible are multi-story and located in densely populated urban environments, available rooftop area is a valuable commodity that should be optimized for PV and SHW installations.

GSA is responsible for over 354 million square feet $\left(\mathrm{ft}^{2}\right)$ of federally owned and leased space in more than 9,600 buildings. ${ }^{1} \mathrm{~A}$ large percentage of those facilities are candidates for rooftop solar installations. The Energy Policy Act of 2005 (EPAct) requires that the Secretary of Energy ensure that, to the extent economically feasible and technically practicable, not less than $7.5 \%$ of the total electricity consumed by the Federal Government come from RE in FY 2013 and thereafter. The Energy Independence and Security Act of 2007 (EISA) also requires new federal buildings and major renovations meet $30 \%$ of their hot water demand with solar energy, provided it is cost-effective over the life of the system. According to the 2007 annual report to Congress, GSA ranks second in the Federal Government for the use of onsite RE with 228,791 megawatt-hours per year (MWh/year) of RE electricity production, or $8.2 \%$ of GSA's total electricity usage. GSA plans to continue its proactive stance toward on-site RE implementation by identifying cost-effective, innovative technology solutions.

The solar energy industry is among the most dynamic industries in the energy sector, and is experiencing revolutionary reductions in installed costs and innovative technology offerings. Due to the liquidity of the market and the pace that new technologies enter the market, emerging technologies need to be tested in the field to evaluate their actual in-situ performance.

\section{What is the technology?}

Photovoltaic-thermal (PV-T) technology consists of a typical solar PV panel, coupled with a solar thermal collector installed on the back of the PV panel to pre-heat domestic hot water (DHW) or ventilation air. This allows a larger portion of the solar energy incident on the collector to be turned into useful thermal and electrical energy. A primary feature of this system is that the efficiency of a PV panel decreases as the cell temperature increases. Water or air flowing through the thermal collector removes heat from the PV cells, allowing for more efficient operation. In addition, water or air heating and electricity can be produced within the same footprint, resulting in more efficient use of valuable roof space.

There are a number of different types of PV-T technologies. Each technology has different target applications, installed costs and performance characteristics. For this demonstration, a hybrid PV-T solar energy system was installed at the Thomas P. O'Neill, Jr. Federal Building (O'Neill Federal Building) in Boston, MA as part of a research effort to evaluate emerging technologies through the GSA Green Proving Ground (GPG) program. This type of thermal collector wicks heat from the backs of PV modules

${ }^{1}$ GSA Properties Overview, available at: http://www.gsa.gov/portal/content/104501 
as a means of pre-heating DHW for the facility. Funded by the American Recovery and Reinvestment Act of 2009 (ARRA), the project was the largest rooftop hybrid solar installation in the country when it was installed and the first of its kind on a federal building. While the PV-T technology has evolved over time and now covers domestic hot water, ventilation air and radiant floor heating, this evaluation is focused on a traditional solar hot water and PV application.

The system on the O'Neill Federal Building is rated at 31.5-kilowatt (kW) electric and 69-kW of thermal energy. The overall PV array consists of two subarrays of 75 modules and 150 modules in total. The PV panels are made of multi-crystalline silicon. They are rated at 210 watts (W) and have a rated electrical efficiency of $13.4 \%$. The thermal system on the O'Neill Federal Building consists of three hot water loops, each of which has 48 thermal collectors and 160 gallons of storage in two 80-gallon tanks, for a total of 144 collectors and 480 gallons of storage. Of the 150 PV panels, 144 have solar thermal collectors installed on the back, leaving 6 PV panels without the thermal backing. The solar installer installed 6 panels without thermal backing to provide a means of evaluating the performance of the PV panels without solar thermal panels. The original design goal for the SHW system was to meet $20 \%$ of the building's DHW load.

\section{Study design and objectives}

The demonstration project was hosted by GSA Region 1, at the O'Neill Federal Building in Boston, MA. The O'Neill Federal Building is comprised of an 11-story high-rise section and a 5-story low-rise section connected by a 5-story interior courtyard covered by a continuous skylight. A total of 28 agencies occupy the facility, which has received an ENERGY STAR ${ }^{\circledR}$ certification. The PV-T system was installed on the roof of the facility's five-story low-rise section. PV-T is an early commercial technology. One of the study's primary goals was to identify what worked in the O'Neill Federal Building's PV-T system and what needed improvement.

\section{Project Results/Findings}

Because of complications in system design and conflicts in installation and commissioning, not uncommon in the deployment of early commercial technologies, the M\&V process did not deliver results that would be representative of future installations. It did, however, provide numerous lessons in system design as well as a list of best practices. The lessons learned from the demonstration were used to inform future designs and a model was created for the "ideal" PV-T system design for this particular facility. The ideal system was modeled per the manufacturer's recommendations. TRNSYS was used to model the solar thermal system and SolOpt was used to model the impacts of panel cooling on PV production. The basic system characteristics of the ideal system are outlined below:

- 48 solar thermal collectors installed on the back of typical crystalline silicon PV panels

- 480 gallons of storage

- Typical Office building draw profile (1,300 gallons/day on weekdays and 0 gallons/day on weekend)

- 150-Watt circulation pump

- Standalone boiler provides supplementary heating (electric boiler)

- Tank temperature set point $125^{\circ} \mathrm{F}$

- Mixing valve set point temperature $120^{\circ} \mathrm{F}$ 
The system was modeled in six locations with different weather files, and utility rates, and of the six locations modeled (see Table 1), only Honolulu, $\mathrm{HI}$, and Daggett, CA, which had an electric hot water backup system, met the federal life-cycle costing requirements, with a net present value greater than $\$ 0.00$ over a 40 -year analysis period. With a 30\% Federal Tax Credit, all cities except Portland, OR and Boston, MA are life-cycle cost-effective.

Table 1 - Ideal PV-T System Simple Payback Including Increased PV Production

\begin{tabular}{||l|c|c|c|c|c|c||}
\hline City & $\begin{array}{c}\text { Electricity } \\
\text { Rate } \\
\mathbf{( \$ / k W h )}\end{array}$ & $\begin{array}{c}\text { City Cost } \\
\text { Adjustment } \\
\text { Multiplier }\end{array}$ & $\begin{array}{c}\text { Solar } \\
\text { Energy } \\
\text { Production } \\
\text { (kWh/yr) }\end{array}$ & $\begin{array}{c}\text { Annual } \\
\text { Cost } \\
\text { Savings (\$) }\end{array}$ & $\begin{array}{c}\text { Installed } \\
\text { Cost (\$) }\end{array}$ & $\begin{array}{c}\text { Simple } \\
\text { Payback } \\
\text { (yrs) }\end{array}$ \\
\hline Portland, OR & 0.0868 & 0.992 & 6,698 & $\$ 581$ & $\$ 56,765$ & 98 \\
\hline Boston, MA & 0.1476 & 1.172 & 6,331 & $\$ 934$ & $\$ 67,065$ & 72 \\
\hline Denver, CO & 0.1083 & 0.943 & 11,063 & $\$ 1,198$ & $\$ 53,961$ & 45 \\
\hline Honolulu, HI & 0.3454 & 1.173 & 10,097 & $\$ 3,488$ & $\$ 67,123$ & 19 \\
\hline Daggett, CA & 0.1813 & 0.996 & 11,824 & $\$ 2,144$ & $\$ 56,994$ & 27 \\
\hline Phoenix, AZ & 0.105 & 0.887 & 11,783 & $\$ 1,237$ & $\$ 50,757$ & 41 \\
\hline
\end{tabular}

Future GSA installations should focus, therefore, on locations with characteristics similar to Hawaii or Daggett CA and which meet all of the following requirements:

Limited Roof Space - Facilities with limited roof space relative to the size of the electrical and thermal load that are looking to fill the entire roof with solar and maximize solar energy production should be targeted. These facilities are ideal candidates for PV-T as more energy can be produced from the same footprint than a separate PV and solar thermal system.

- High Energy Costs - The natural gas industry has experienced significant cost reductions over the last few years. The economics of the solar thermal system is sensitive to fuel source costs and the cost of electricity on a $\$ / M M B t u$ basis is seven times higher than natural gas in Boston MA. In addition the modeling analysis showed that $\mathrm{HI}$ and Daggett CA were the only locations where the system was cost effective without federal incentives. For installations where the federal tax credit cannot be captured sites with electric rates of 30 cents/kWh or higher should be targeted, and for systems that can capture the federal tax incentives sites with electric rates of 15 to 20 cents/kWh or higher should be targeted.

- Hot Climates - PV-T systems were shown to have the best economics in warmer locations such as Phoenix AZ, Dagget CA, and Honolulu HI. A PV-T system will produce more hot water on an annual basis in these locations which increases the thermal energy savings. PVT systems were also shown to provide additional PV panel cooling benefits in hot locations since the panel temperatures are hotter in these locations and the impact on increased electrical production has a bigger impact on the overall economics. Systems with both hot climates and high utility rates should be targeted for future installations.

- Central Hot Water Systems - Facilities with centralized domestic hot water systems should be targeted for the PV-T technology and the baseline DHW load should be metered before 
designing a solar thermal system in order to size the system properly. Facilities with small de-centralized point of use domestic hot water systems are not applicable for solar thermal installations.

- Piping Costs - Piping costs need to be considered in future installations. The length of the home run and overall piping costs should as short as possible to minimize installation costs.

In addition to the specific requirements a number of general solar thermal design best practices and lessons learned are outlined below:

- Implement efficiency first - The existing DHW equipment should be analyzed prior to the installation of a SHW system. All applicable water conservation and energy efficiency opportunities should be implemented before sizing a solar thermal system.

- Use accurate component and system design tools to optimize performance - PV-T is a relatively new technology and design tools are still in development to model the solar thermal system and effects on the PV system. For future designs, a detailed hourly analysis should be conducted with SRCC-rated solar thermal panel performance data. This will aid in the correct sizing of the system and enable a more accurate economic analysis.

- Design systems with the same unit flow rate $\left(\mathrm{gpm} / \mathrm{ft}^{2}\right)$ at which the panels were tested - The flow rates through each solar thermal panel should be set to SRCC test conditions, which in this case was a $0.0281 \mathrm{gpm} / \mathrm{ft}^{2}$ collector area.

- Carefully select heat exchangers - The solar thermal heat exchangers between the collection loops and storage tanks should be properly sized to avoid an adverse impact on system performance. The thermal tanks should be sized appropriately based on the solar thermal fraction, design inlet temperature, outlet temperature, and flow rates.

- Install sub metering - Sub metering should be installed and used to report thermal energy production and compare it to predicted energy production on a monthly basis.

\section{Conclusions}

The advantages of the PV-T technology installed in Boston are associated with the ability to install a PV and solar thermal system in the same footprint, the ability to simultaneously increase PV electrical production, and the potential to meet the federal requirement that mandates $30 \%$ of hot water loads be satisfied with solar thermal in new construction and major renovations, where life-cycle cost-effective.

The primary disadvantage of the technology is the lower thermal efficiency, which requires greater surface area to provide an equivalent amount of solar thermal energy. Ultimately, the total system cost must be $30 \%$ to $50 \%$ lower than the cost of traditional solar thermal systems to be cost competitive.

In the future, the technology should be evaluated against a standard solar thermal and separate PV system by an independent energy analyst using an hourly analysis tool. Installations should focus on hotter climates with good local solar incentives, facilities with electric hot water heaters, and high electric rates that can fully capture the benefits of panel cooling and apply the best practices listed above. Of the six locations modeled, only Honolulu, $\mathrm{HI}$, which had an electric hot water backup system, met the federal life-cycle costing requirements, with a net present value greater than $\$ 0.00$ over a 40 year analysis period. 


\section{Background}

\section{A. Assessment}

Solar energy technologies offer a number of strategic benefits to the United States. Replacing fossil fuelfired generators with solar energy reduces emissions of human-induced greenhouse gases (GHGs) and air pollutants. Sunlight is a free resource. Therefore, once solar technologies are installed, they have very low operating costs and require minimal non-solar inputs. This provides insurance against conventional fuel supply disruptions and price volatility. In addition, growing the domestic solar energy industry could establish the U.S. as a global leader in solar technology innovation and support a growing number of solar-related jobs.

Despite these benefits, solar energy currently supplies only a small fraction of U.S. energy needs, primarily because, historically, it has been more expensive than conventional energy sources. However, solar manufacturing costs and sales prices have dropped dramatically over the past few decades, and solar technologies are approaching energy-price parity with conventional generating sources in some regions of the U.S. and abroad. Further, experience accumulated by solar manufacturers and developers, utilities, and regulatory bodies has decreased the time and expense required to install a fully operating solar system. These gains have come through both research and development (R\&D) and U.S. and global solar market stimulation. An additional strong, coordinated effort could enable solar energy technologies to become increasingly cost competitive with conventional electricity-generation technologies in the U.S. over the next decade.

\section{Photovoltaic}

In 2010, solar energy provided less than $0.1 \%$ of U.S. electricity demand. This is comparable to the amount supplied by nuclear energy in 1960, which subsequently grew to $11 \%$ by 1980 and to $19 \%$ by 1990. Over the past decade, U.S. solar deployment has lagged behind deployment in European and Asian countries, primarily because these countries instituted strong solar-promoting policies, while solar policies in the United States were limited and inconsistent.

Figure 1 shows the regional photovoltaic (PV) cell and module shipments from the U.S., Japan, Europe, China/Taiwan, and the rest of the world (ROW) over the past decade. ${ }^{2}$ Between 2000 and 2010, PV module shipments achieved a compound annual growth rate of $53 \%$, reaching 17 gigawatts (GW) of annual module shipments in 2010, and bringing the cumulative global PV shipments to about $40 \mathrm{GW}$. Although the U.S. accounted for $30 \%$ of global shipments in 2000 , the U.S. market share declined significantly during the past decade. In 2010, the U.S. accounted for only 6\% (about 1,000 MW) of PV module supply and only $8 \%$ (or about $1,400 \mathrm{MW}$ ) of demand. ${ }^{3}$ By mid-2011, continued R\&D and market forces helped reduce PV prices sharply and, along with a mix of state and federal policies, have positioned the U.S. PV market for rapid future growth.

\footnotetext{
${ }^{2}$ Mints, P. (2011a). Photovoltaic Manufacturer Shipments, Capacity \& Competitive Analysis 2010/2011. Palo Alto, CA: Navigant Consulting Photovoltaic Service Program. Report NPS-Supply6 (April 2011).

${ }^{3}$ Mints, P. (2011b). Analysis of Worldwide Markets For Solar Products \& Five-Year Application Forecast 2010/2011. Palo Alto, CA: Navigant Consulting Photovoltaic Service Program. Report NPS-Global6 (August 2011).
} 


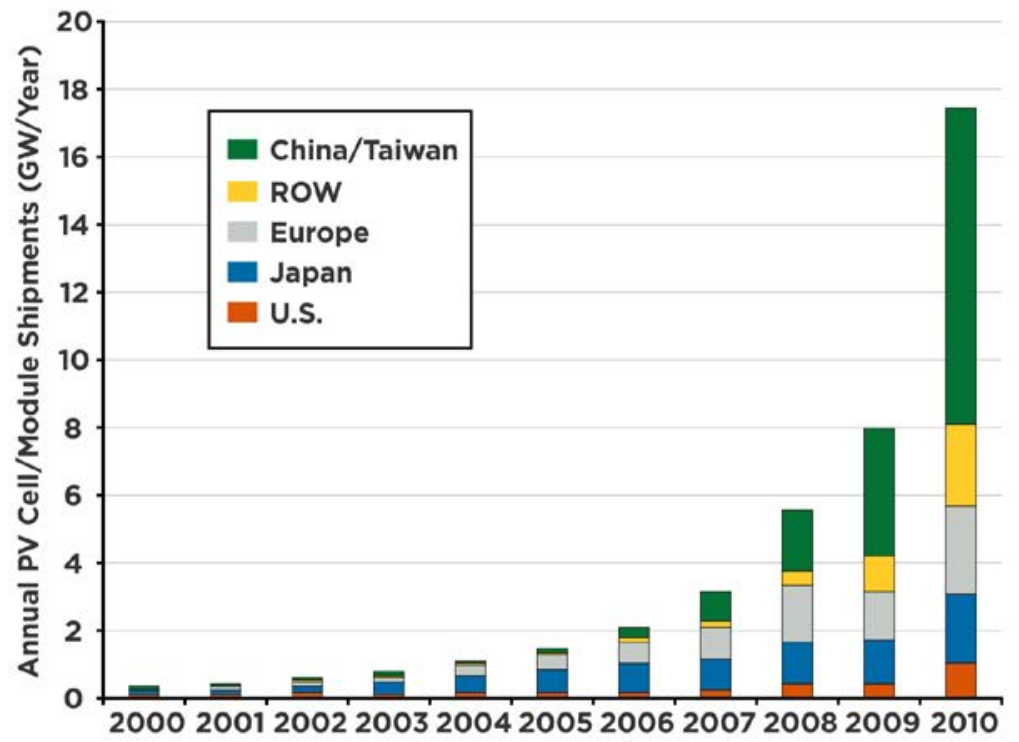

Figure 1. Regional PV cell and module shipments, 2000 to 2010

Solar Thermal

According to the Energy Information Administration (EIA), water heating accounted for $6.7 \%$ of commercial building energy use, and solar energy supplied approximately 2\% (0.05 Quads/year) in 2010. ${ }^{6}$ EIA also estimated that $3 \%$ of buildings have solar thermal systems and, for the facilities that have solar thermal, approximately one third of the DHW load is supplied by the on-site solar thermal system.

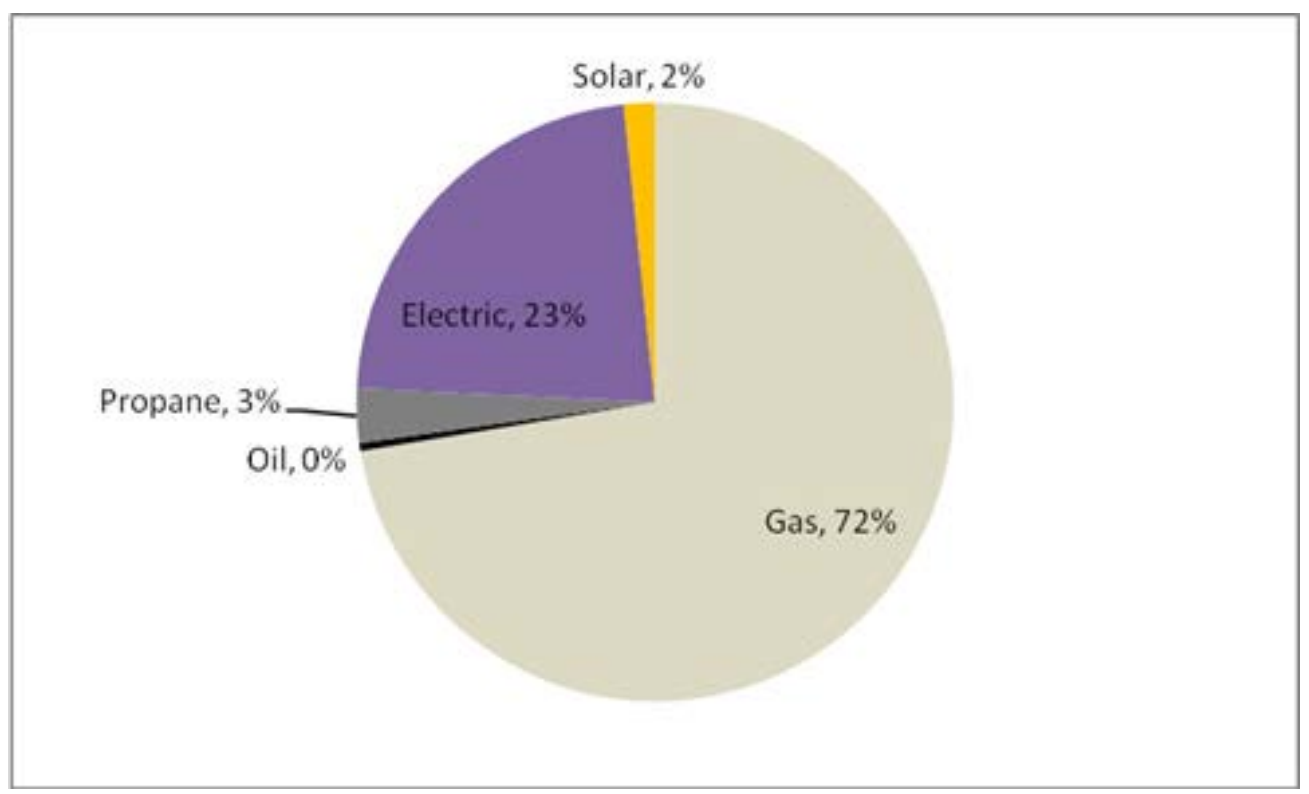

Figure 2. Domestic hot water fuel sources 
Domestic hot water (DHW) systems are primarily served by electric and natural gas heating systems, with the majority of the heating coming from natural gas. ${ }^{4}$ Facilities switching to solar thermal that currently use electric hot water heating will have better economics than facilities with natural gas heating systems, due to the increased cost of electricity on a \$/MMBtu basis. ${ }^{5}$

In 2009, there were 88 manufacturers or importers, or both, active in manufacturing, importing, and exporting solar thermal collectors-an $18.9 \%$ increase from the 74 companies operating in 2008 . These companies shipped 13.8 million square feet of solar thermal collectors in 2009 , compared to 17.0 million square feet in $2008 .^{6}$

Of the 88 companies reporting solar thermal collector shipments in 2009, many manufacturers also reported being involved in one or more of the following solar thermal-related activities:

- 59 designed collectors or systems

- 27 developed prototype collectors

- 23 developed prototype systems

- 61 were involved in wholesale distribution

- 31 were involved in retail distribution

- 27 installed collectors.

In 2009, low-temperature and unglazed solar collector shipments in the U.S. totaled 10.5 million $\mathrm{ft}^{2}$, about 3.5 million $\mathrm{ft}^{2}$ less than the shipments in 2008. Nearly 94 percent of low-temperature collectors are used in the residential sector, primarily for pool heating. However, shipments to the pool heating market fell by more than 25 percent in 2009 compared with shipments in 2008 , due partly to declines in U.S. home sales and prices, and the economic downturn.

U.S. shipments of medium-temperature collectors (defined in the Technology Description section) totaled 2.3 million $\mathrm{ft}^{2}$ in 2009 , nearly 10 percent less than the shipments of approximately 2.6 million $\mathrm{ft}^{2}$ in 2008. The decrease in shipments is believed to be mainly due to the economic recession.

Approximately 87 percent of medium-temperature collectors are used for hot water heating. ${ }^{6}$

\section{B. Opportunity}

The U.S. General Services Administration (GSA) is responsible for over 354 million $\mathrm{ft}^{2}$ of federally owned and leased space in more than 9,600 buildings. ${ }^{7}$ A large percentage of those facilities are candidates for rooftop solar installations. The Energy Policy Act of 2005 (EPAct) requires that the Secretary of Energy ensure that, to the extent economically feasible and technically practicable, not less than $7.5 \%$ of the total electricity consumed by the Federal Government come from renewable energy (RE) in FY 2013 and thereafter. According to the 2007 annual report to Congress, GSA ranks second in the Federal Government for the use of onsite RE with $228,791 \mathrm{MWh} /$ year of RE electricity production, or $8.2 \%$ of GSA's total electricity usage.

\footnotetext{
${ }^{4}$ The DOE Buildings Energy Data Book, available at: http://buildingsdatabook.eren.doe.gov/TableView.aspx?table=3.1.4

${ }^{5} \mathrm{MMBTu}=$ One million British thermal units (BTU)

${ }^{6}$ EIA Solar Thermal Collector Manufacturing Activities 2009, available at: http://www.energybc.ca/cache/solarthermal/www.eia.gov/renewable/annual/solar_thermal/solar.html

${ }^{7}$ GSA Properties Overview, http://www.gsa.gov/portal/content/104501
} 
Targeting energy consumption in federal buildings, the Energy Independence and Security Act of 2007 (EISA) also requires new federal buildings and major renovations to meet $30 \%$ of their hot water demand with solar energy, provided it is cost-effective over the life of the system. Federal facilities having financial difficulty meeting the EISA mandate (e.g., facilities with natural gas) can potentially take advantage of PV-T systems to meet both the EPAct 2005 and EISA 2007 renewable energy requirements. The PV-T technology is typically designed for lower solar fractions and operating temperatures; these systems are potentially capable of meeting the statutory requirements of $30 \%$ solar fractions costeffectively in certain locations and utility markets. The solar fraction is defined as the percentage of the overall DHW load over the course of a year that is supplied by an SHW system.

Although solar energy's contribution to U.S. energy supply has been small to date, its technical potential is enormous. For example, one estimate suggested that the area required to supply an amount of electricity equivalent to all end-use electricity in the U.S. using PV is only about $0.6 \%$ of the country's total land area. ${ }^{8} \mathrm{~A}$ recent estimate of the total roof area suitable for PV in the U.S. is about 64.5 billion $\mathrm{ft}^{2}$, even after eliminating $35 \%$ to $80 \%$ of roof space to account for panel shading (e.g., by trees) and suboptimal roof orientations. With current PV performance, this area has the potential for more than $600 \mathrm{GW}$ of PV capacity. ${ }^{9}$ The U.S. had $1,051 \mathrm{GW}$ of electrical generating capacity in $2011 .{ }^{10}$

In a strategic attempt to reduce the installed cost of PV systems, the U.S. Department of Energy (DOE) launched the SunShot Initiative in February 2011. ${ }^{11}$ This Initiative is a collaborative national effort to make solar energy cost competitive with other forms of energy by the end of the decade. Achieving this goal will require dramatic decreases in the cost structure of solar technologies-on the order of a 75\% reduction-across all markets, including residential, commercial, and utility-scale deployments of solar. To do this effectively, the SunShot Initiative spans the full spectrum from basic science to applied research and development. It also spans across multiple DOE offices, including Energy Efficiency and Renewable Energy (EERE), Advanced Research Projects Agency- Energy (ARPA-E) and the Office of Science (SC).

The SunShot program is targeting a reduction in installed costs to $\$ 1.00 / D C-W a t t$ for utility scale solar in 2020 , and $\$ 1.25 / D C-W a t t$ for commercial rooftop solar. The 2010 benchmark prices for the SunShot vision study are \$4.00/DC-Watt for utility scale solar in 2010 and \$5.00/DC-Watt for commercial rooftop solar. Achieving the SunShot targets is projected to result in the cumulative installation of approximately $302 \mathrm{GW}$ of PV and $28 \mathrm{GW}$ of concentrating solar power (CSP) by 2030. A recent study indicates that under these assumptions, solar electricity could contribute up to $14 \%$ and $27 \%$ of the total electricity demand by 2030 and 2050, respectively. ${ }^{12}$

These drastic reductions in installed costs will drive cost-competitive installations at federal facilities and provide a potential opportunity to marry the technology with a low cost solar thermal option that can meet $30 \%$ of the DHW needs of a facility.

\footnotetext{
${ }^{8}$ This calculation is based on deployment/land in the entire United States (including Alaska and Hawaii).

${ }^{9}$ Denholm, P.; Margolis, R. (2008a). "Land-Use Requirements and the Per-Capita Solar Footprint for Photovoltaic Generation in the United States." Energy Policy; 36:3531-3543.

${ }^{10}$ Electricity Generating Capacity, http://www.eia.gov/electricity/capacity/

${ }^{11}$ DOE Sunshot Initiative, http://www1.eere.energy.gov/solar/sunshot/index.html

${ }^{12}$ DOE SunShot Vision Study, http://www.nrel.gov/docs/fy12osti/47927.pdf
} 


\section{Technology Description}

\section{Traditional Solar Hot Water}

Solar water heating systems use solar collectors to capture sunlight to heat water (or an antifreeze liquid) that is then moved from the collector to a storage tank (Figure 3). There are two types of systems, active and passive. Active systems use electricity to pump the fluid and have a reservoir or tank for heat storage and subsequent use. Passive systems rely on natural convection and water pressure during draw to move fluids and require no circulation hardware. The systems may be used to heat water in homes, businesses, and for industrial uses. In many climates, a SHW system can provide up to $80 \%$ or more of the energy needed to heat water. SHW systems almost always require a backup system for cloudy days and times of increased demand. Conventional natural gas or electric water heaters typically provide backup, so hot water is always available regardless of the weather or demand.

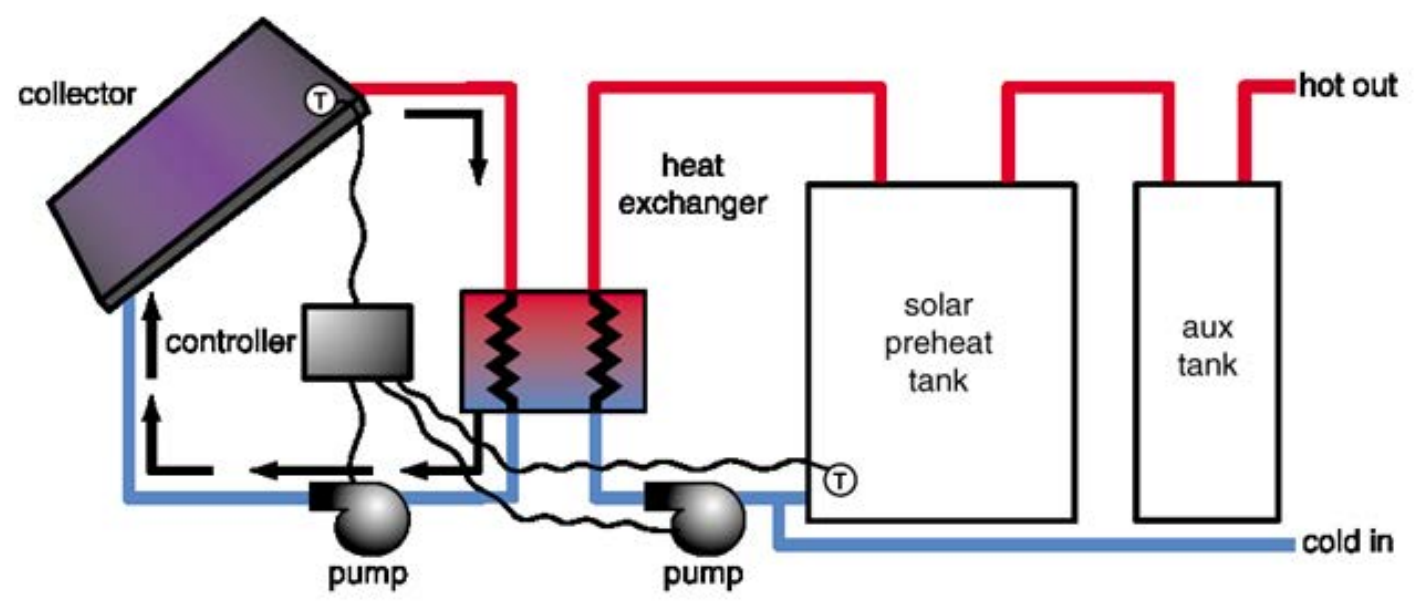

Figure 3. Schematic of an active SHW system with freeze protection (Illustration by Jim Leyshon, NREL)

\section{Collectors}

There are primarily three types of solar collectors used for common solar water heating systems: unglazed, flat plate, and evacuated tube. A fourth type of collector, parabolic trough, is only used to heat water for very large facilities or for high-temperature applications, including electric generation. Typically, unglazed collectors are used for heating pools and house a dark absorber plate (metal or plastic) without a cover. Conventional flat-plate collectors are insulated boxes with glass covers that contain a dark thin copper plate used to absorb the sun's heat underneath. The terms single- and double-glazed collector come from the glass plate on the flat-plate collector. The collector housing is typically steel or aluminum. Evacuated-tube solar collectors use transparent glass tubes that contain a metal absorber tube attached to a fin. Most collectors sold in the U.S. today are flat-plate collectors, which constitute over $90 \%$ of the market. An illustration of the four solar thermal technologies is provided in Figure 4. 


\section{Unglazed EPDM Collector}

Extruded "Mat" with Flow Passages

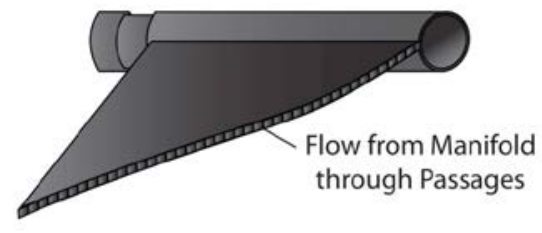

Evacuated Tubes

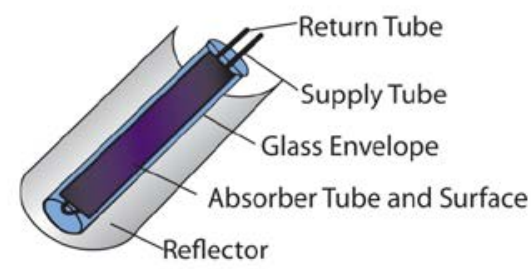

\section{Flat Plate Collector}
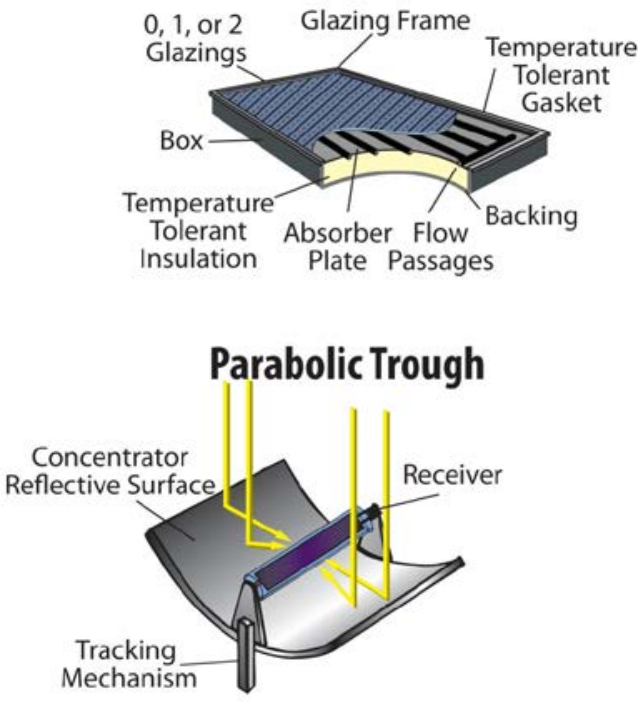

Figure 4. Solar thermal technologies, with unique characteristics shown (Illustration by Jim Leyshon, NREL)

\section{Storage Tanks}

Typically, storage is required to couple the timing of the intermittent solar resource with the timing of the hot water load. Usually, one to two gallons of storage water per square foot of collector area is adequate. Storage can either be potable or non-potable water if a code-approved load side heat exchanger is used. For conventional small systems, storage is most often in the form of glass-lined steel tanks at line pressure. For large systems, unpressurized storage tanks made of polymers or using polymer liners are common. These can reduce storage cost per unit volume considerably compared to small pressurized tanks.

\section{Traditional Photovoltaic Systems}

PV is a mature, commercially available renewable-energy technology (Figure 5). PV systems convert sunlight directly into electricity without moving parts and without producing air pollution. PV modules increasingly use silicon semiconductor materials, but increasingly also use other materials to convert sunlight directly into electricity. Sunlight enters a PV module and is converted into direct-current (DC) electricity. 


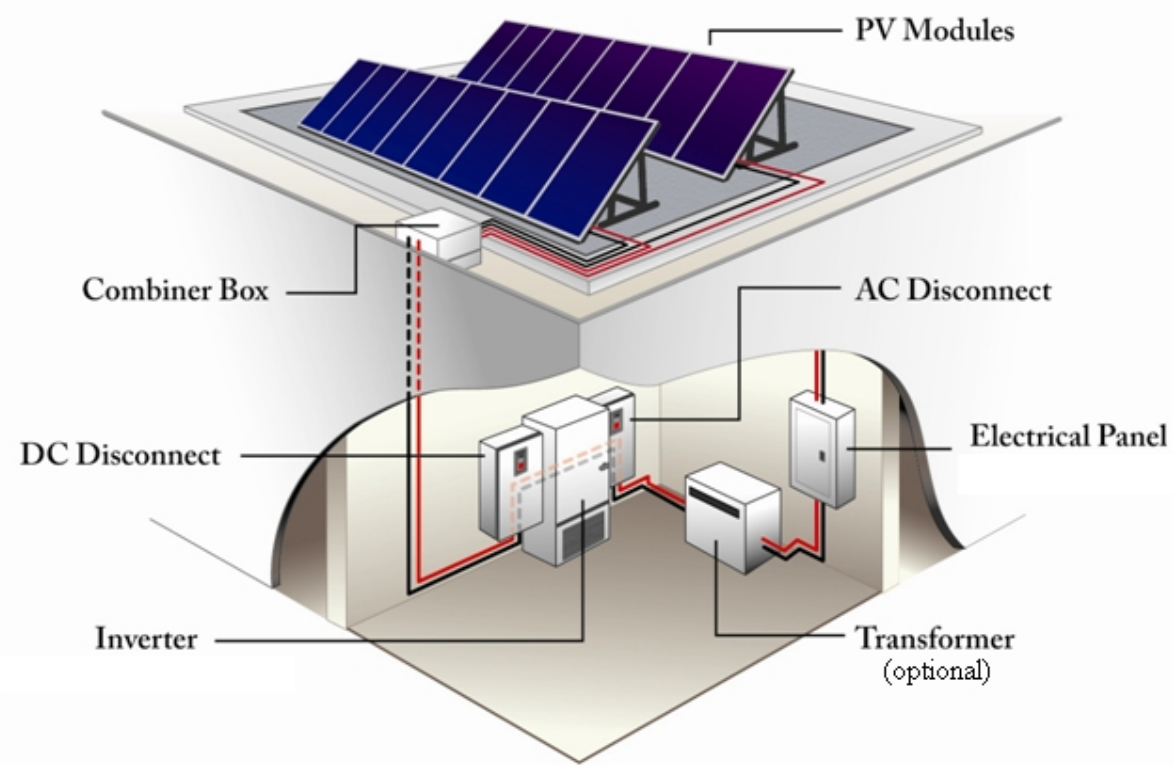

Figure 5. PV System Schematic (Illustration by Jim Leyshon, NREL)

Traditional single-crystalline silicon (Si) solar modules are made with silicon cells, are usually flat-plate, and generally are the most efficient solar modules. Multi-crystalline Si modules are a similar technology, but may be slightly less efficient. A third type of module technology, called thin-film, is made from amorphous Si or a thin layer of non-silicon materials, such as cadmium telluride (CdTe) or copper indium gallium diselenide (CIGS). Thin-film solar cells use layers of semiconductor materials only a few micrometers thick. Table 4 lists some typical efficiencies for each type of module. Module efficiency is important because an array of high-efficiency modules can deliver from two to three times as much power as an array of low-efficiency modules for a given module footprint. Efficiency is measured by calculating the amount of electrical power produced by the PV module, measured in watts $/ \mathrm{meter}^{2}$ $\left(\mathrm{W} / \mathrm{m}^{2}\right)$, divided by the amount of solar energy striking the module, measured in $\mathrm{W} / \mathrm{m}^{2}$.

Table 2: Typical Efficiency Ranges for Different PV Module Technologies ${ }^{13}$

\begin{tabular}{||l|c||}
\hline PV Module Type & $\begin{array}{c}\text { Electrical } \\
\text { Efficiency } \\
\text { Range (\%) }\end{array}$ \\
\hline Single-crystalline silicon & $14 \%$ to $19 \%$ \\
\hline Multi-crystalline silicon & $13 \%$ to $17 \%$ \\
\hline Thin-film & $6 \%$ to $11 \%$ \\
\hline
\end{tabular}

\footnotetext{
${ }^{13}$ Implementing Solar PV Projects on Historic Buildings and in Historic Districts. A. Kandt, E. Hotchkiss, and A. Walker.

National Renewable Energy Laboratory; J. Buddenborg and J. Lindberg National Trust for Historic Preservation. NREL/TP-7A4051297. September 2011.
} 
For applications that are connected to the electrical grid, an inverter transforms this DC electricity into the alternating-current (AC) electricity that can be used by a home or business, or can be exported to the utility grid. PV systems may be installed on the ground, rooftops, parking garages, and awnings. Rooftop PV systems range in size from a few kilowatts (kW) for residential systems to hundreds of kilowatts or megawatts (MW) on large commercial roofs.

\section{PV-T Technology Overview}

PV-T technology is intended to increase the amount of solar energy collected from a solar energy system by combining the PV and solar thermal panels into a single system of collectors. The thermal collector (absorber) is attached to the back of an off-the-shelf PV module, as illustrated in Figure 6.

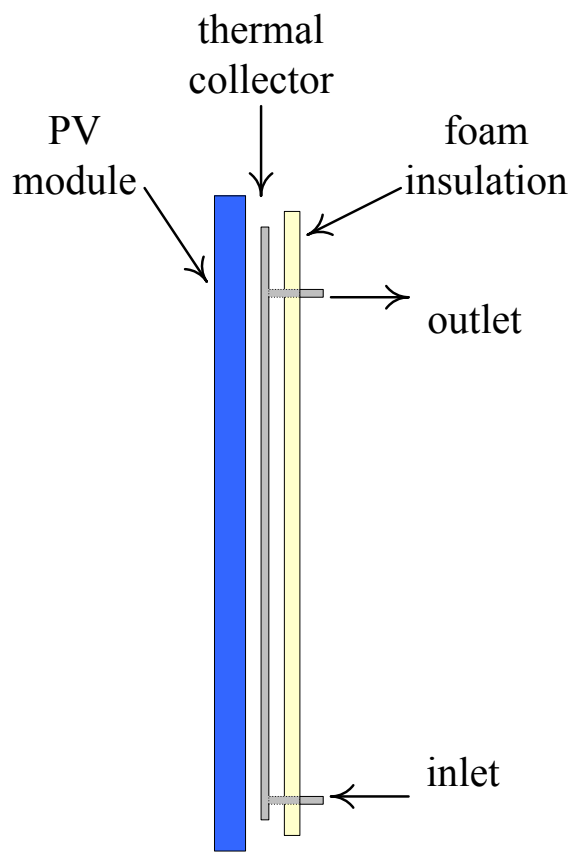

Figure 6. PV-T panel components

The sun does not hit the thermal collector directly; instead the solar energy that is not converted into electricity by the PV panel can be collected as useful heat by the solar thermal collector. This increases the overall efficiency of the system, which is characterized by Equation 1 and Equation 2:

\section{Equation 1: Total Energy Production}

$$
E_{\text {total }}=E_{p v}+Q_{u s e f u l}
$$

Equation 2: Solar Efficiency

$$
E f f_{\text {sys }}=\frac{\text { Sol }_{\text {resource }}}{E_{\text {total }}}
$$


Where

- $\mathrm{E}_{\text {total }}=$ total collected solar energy ( $\mathrm{kWh}$ or MMbtu)

- $E_{p v}=$ total collected electrical energy from PV cells ( $k W h$ or MMbtu)

- $\mathrm{Q}_{\text {useful }}=$ total collected solar thermal energy ( $\mathrm{kWh}$ or $\mathrm{MMbtu}$ )

- $\mathrm{Eff}_{\text {sys }}=$ solar efficiency of system (\%)

- $\quad$ Sol ${ }_{\text {resource }}=$ incident solar radiation $\left(\mathrm{kWh} / \mathrm{ft}^{2}\right)$

Equation 3: PV panel efficiency

$$
\text { Efficiency }=E F F_{\text {ref }} *\left(1+\text { Temp }_{\text {Co }} *\left(T_{\text {ref }}-T_{\text {cell }}\right)\right)
$$

Where

$$
\begin{array}{ll}
\text { Efficiency } & =\text { PV panel efficiency } \\
\text { EFF }_{\text {ref }} & =\text { reference panel efficiency } \\
\text { Temp }_{\text {co }} & =\text { panel power temperature coefficient } \\
\mathrm{T}_{\text {ref }} & =\text { reference temperature }\left(77^{\circ} \mathrm{F}\right) \\
\mathrm{T}_{\text {cell }} & =\text { calculated cell temperature }
\end{array}
$$

The cell temperature is calculated on an hourly basis in SolOpt using Equation 4:

Equation 4: PV cell temperature

$$
T_{\text {Cell }}=T_{O A}+\left(\text { Solar }_{\text {insolation }} * \frac{\left(T_{O p}-T_{\text {ref }}\right)}{\text { Ref } f_{\text {insolation }}}\right) *\left(1-E F F_{\text {ref }}\right)
$$

Where

$$
\begin{array}{ll}
\mathrm{T}_{\text {cell }} & =\text { cell temperature } \\
\mathrm{T}_{\text {oa }} & =\text { outside air temperature } \\
\mathrm{T}_{\text {op }} & =\text { nominal operating temperature } \\
\text { Cell } & =\text { calculated cell temperature } \\
\text { Solar }_{\text {insolation }} & =\text { solar insolation } \\
\text { Ref }_{\text {insolation }} & =\text { reference insolation } \\
\text { Eff }_{\text {ref }} & =\text { reference panel efficiency }
\end{array}
$$

Figure 7 illustrates how the technology is incorporated into a traditional PV module. 

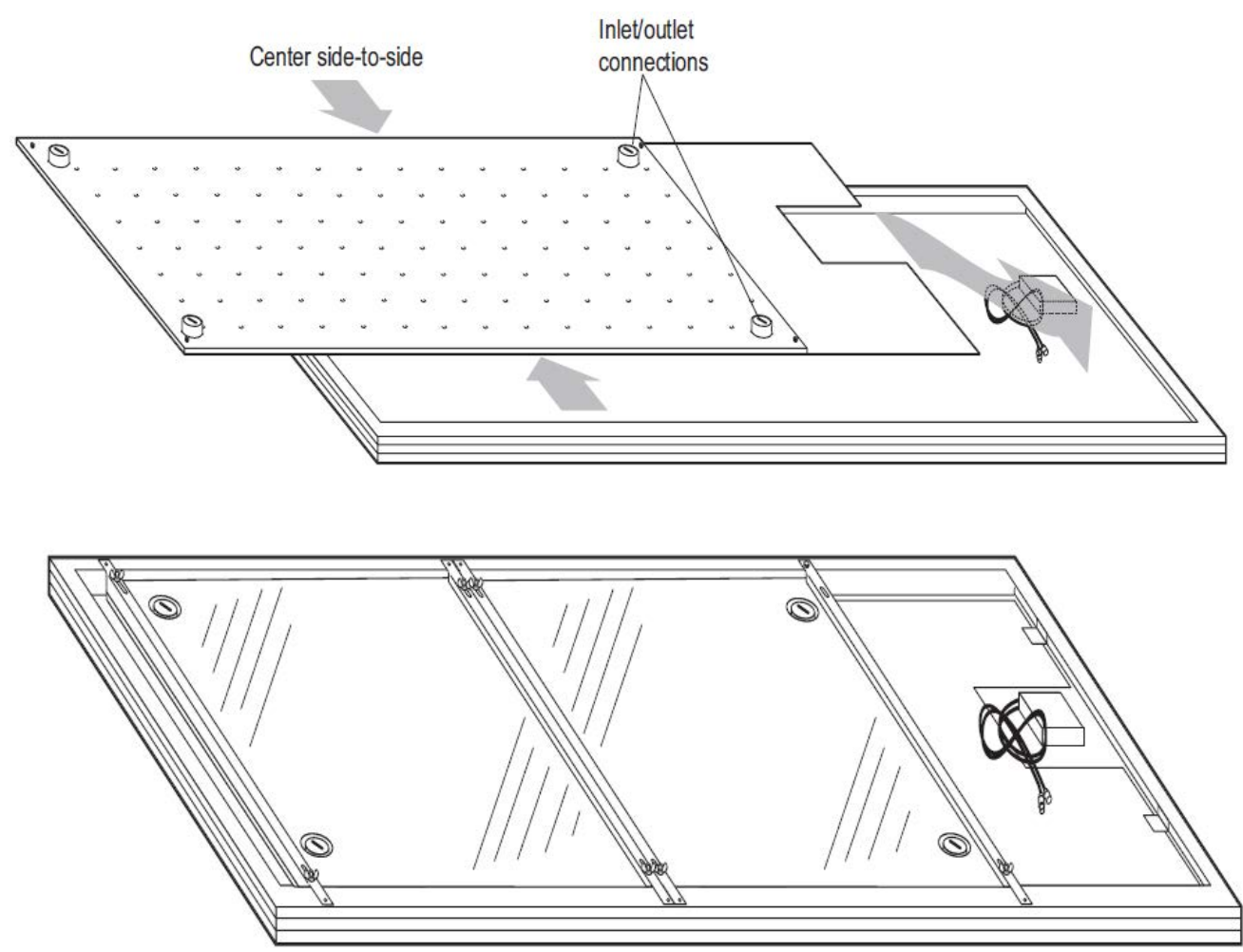

Figure 7. Thermal panel incorporated into a traditional panel ${ }^{14}$

The heat transfer fluid flows in between the thermal collector and PV module. The heat transfer fluid has a single inlet port and outlet port. The rigid insulation behind the thermal collector is $1 / 2$-inch thick. The collector installed in Boston has a total area of $12.486 \mathrm{ft}^{2}$ and an active collector area of $10.2257 \mathrm{ft}^{2}$.

The PV-T system is an active system that uses pumps and a differential controller to start and stop the pumps based on the temperature difference between collector and tank. The Boston PV-T system uses a differential controller that activates the pumps once the temperature difference between the collector and tank is greater than $15^{\circ} \mathrm{F}$.

The solar thermal collection device on the PV-T system operates using the same principles that an unglazed solar thermal collection device uses. The benefit of using unglazed collectors is that the technology has the potential to be less expensive than other types of collectors. Unglazed systems are typically less expensive due to the reduced installed cost of the collector and the fact that they are not subject to temperatures as high as glazed collectors, which also allows for the use of less expensive materials, such as PEX tubing. Additionally, there is no need to purge the thermal component as it will not overheat. In northern climates, the glycol loop assists in melting snow so that the array is able to capture electrical output for greater amount of time than a conventional PV array could.

PV-T systems require a backup heater to meet $100 \%$ of the instantaneous peak hot water demand on cloudy days or when the solar system output is insufficient. Conventional systems are most often sized to meet $60 \%$ to $80 \%$ of the water-heating load, covering most of the load during the summer when temperatures are high, but leaving the system unable to meet the entire winter load. PV-T systems are

${ }^{14}$ SunDrum Solar - Hybrid Solar Collector Assembly Guide REV 004 
usually designed to meet $30 \%$ of the water heating load, because they operate at lower temperatures and have lower thermal efficiencies than traditional flat-plate or evacuated-tube collectors.

The solar thermal product can be installed on the back of PV modules in the field and has been designed to fit a number of different PV panels. Because PV modules are semiconductor devices, the power output of these modules decreases as temperature increases. PV panel manufactures provide a power temperature coefficient that can be used to characterize the effect of panel temperature on overall efficiency. Figure 8 lists the panel efficiencies as a function of cell temperature. The heavy dashed vertical line represents $77^{\circ} \mathrm{F}$, the temperature at which all PV modules are rated.

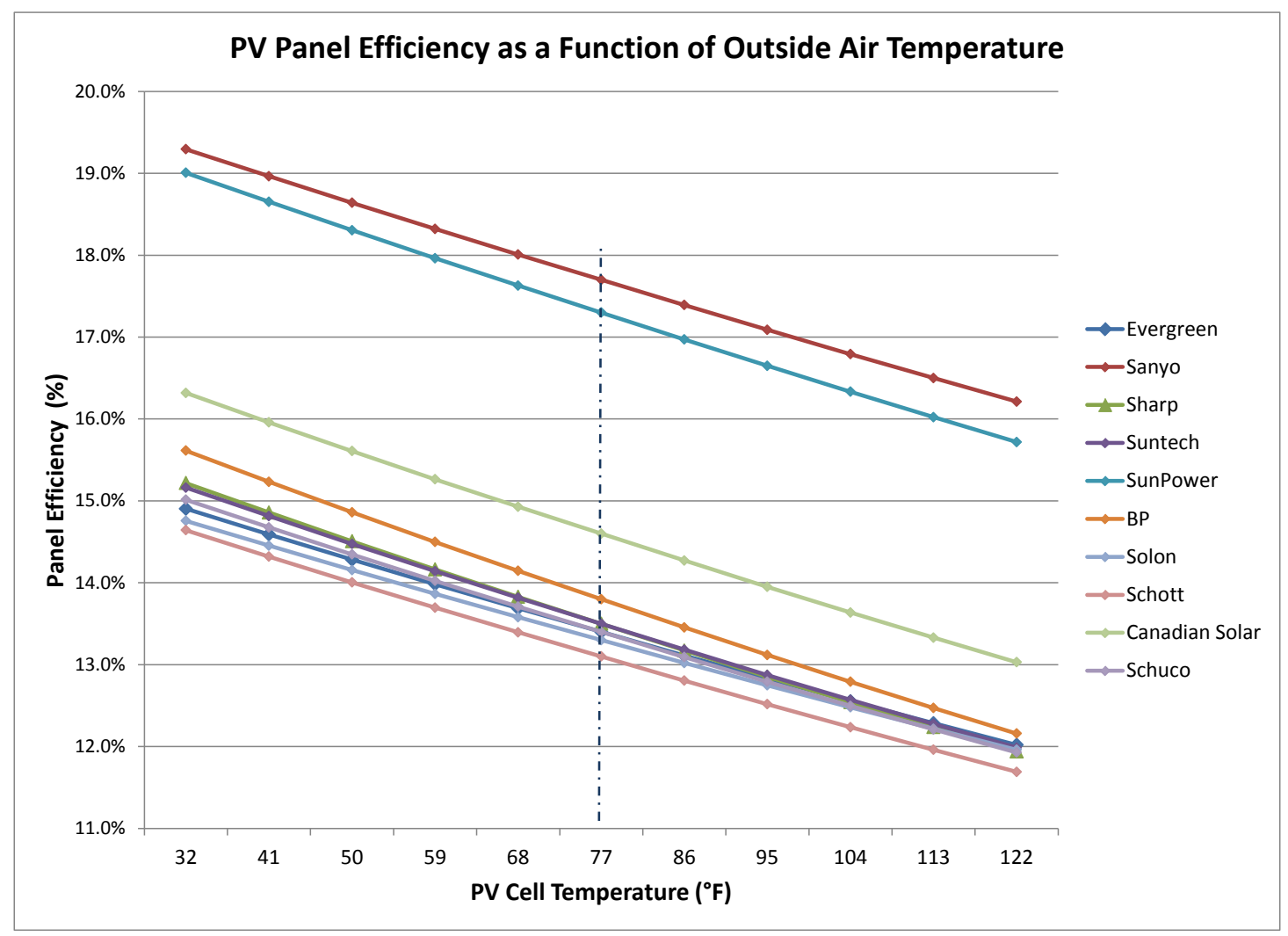

Figure 8. PV efficiency versus cell temperature

Although panel efficiency is a function of panel temperature, a significant reduction in panel temperature is required to achieve a noticeable increase in electricity production. For example, if the PV cell temperature for the Evergreen solar panel is reduced from $122^{\circ} \mathrm{F}$ to $86^{\circ} \mathrm{F}$, a $36^{\circ} \mathrm{F}$ reduction in panel temperature, the PV panel efficiency only increases from $13.1 \%$ to $14.2 \%$.

In summary, the combined PV-T panel provides the following potential synergies:

- The PV module is typically $6 \%$ to $20 \%$ efficient (including thin film and high performance multijunction silicon, not shown in Figure 9 ). The lost energy ( $80 \%$ to $94 \%$ of the incident solar radiation) is mostly converted to heat and a portion of this energy can be used to satisfy thermal heating loads.

- PV modules operate more efficiently when PV surface temperatures are lower. The thermal collectors can lower the PV temperatures under the right conditions. 
- By combining the two technologies, the efficiency of the PV-T system is increased, resulting in a higher power production per unit of solar collector area. This can be important in large commercial buildings, where the roof area may be the only space available for distributed-generation PV. 


\section{M\&V Evaluation Plan}

\section{A. Test Plan}

The PV-T system on the O'Neill Federal Building was studied to characterize its performance; collect performance data that can be used to compare the performance of the system to traditional PV and SHW systems; estimate energy usage and energy cost savings; and assess the technology for broader application by GSA. The study included seven months of continuous monitoring to determine system performance and identify potential performance issues. Although the system was monitored for seven months the results of the onsite measurement and verification effort are not included here because they were not representative of future installations and don't accurately portray the potential energy savings of the given technology. Thus, the test plan and measurement and verification results were excluded from the final report.

\section{B. Facility Description}

The demonstration project was hosted by GSA Region 1 at the O'Neill Federal Building in Boston, MA (Figure 9). The O'Neill Federal Building is comprised of an 11-story high-rise section and a five-story lowrise section connected by a five-story interior courtyard covered by a continuous skylight. The building is $670,818 \mathrm{ft}^{2}$.

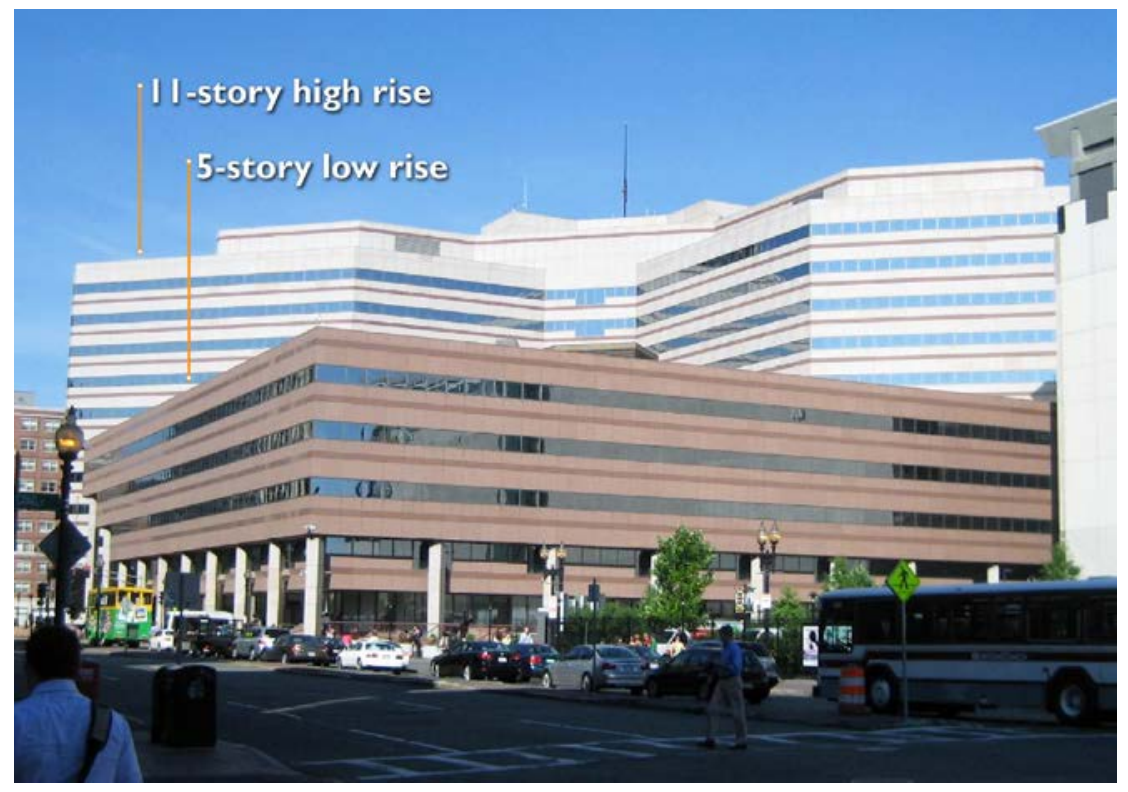

Figure 9. Thomas P. O’Neill Jr. Federal Building

The office building is located in Boston next to North Station, one of Boston's main commuter rail stations. Constructed in 1986, the building has been well maintained and is in excellent condition. Below grade, on a single level, there is parking for 261 vehicles. Amenities include an auditorium, fitness center, cafeteria, and credit union. The building is not a designated historic building.

The building is named after Thomas P. O'Neill Jr., also known as Tip O'Neill, who served as a Congressman from Boston for 34 years and Speaker of the House of Representatives for 10 years. Five federal agencies account for approximately $50 \%$ of the building's current occupancy, with the balance allocated to over 28 agencies. The facility has received an ENERGY STAR certification, and has 
implemented a number of sustainability measures, including the installation of a white reflective roof, low VOC paints, recycled content metal studding, and recycled content ceiling tiles.

\section{Technology Specification}

The PV-T system demonstration consists of a system of PV and solar thermal technologies. The PV components include PV panels, a ballasted mounting system, combiner boxes, wiring and inverters. The solar thermal consists of solar thermal collectors, distribution piping, pumps, storage tanks, heat exchangers, and an onsite boiler to provide make-up thermal energy.

\section{Technology Deployment}

The O'Neill Federal Building was selected for this demonstration project because it had no renewable energy systems prior to the demonstration and is also a regional headquarters for several federal agencies, which would expand the project's potential visibility. Onsite personnel were originally considering a standalone PV system, but the current federal mandates and executive orders led them to consider a joint PV-T installation.

The PV-T hybrid solar energy system that was installed is rated at 31.5-kW electric and an equivalent of 69-kW of thermal energy. This ARRA-funded project was the largest rooftop hybrid solar installation in the country when it was installed in 2011 and the first of its kind on a federal building (Figure 10 and Figure 11). 


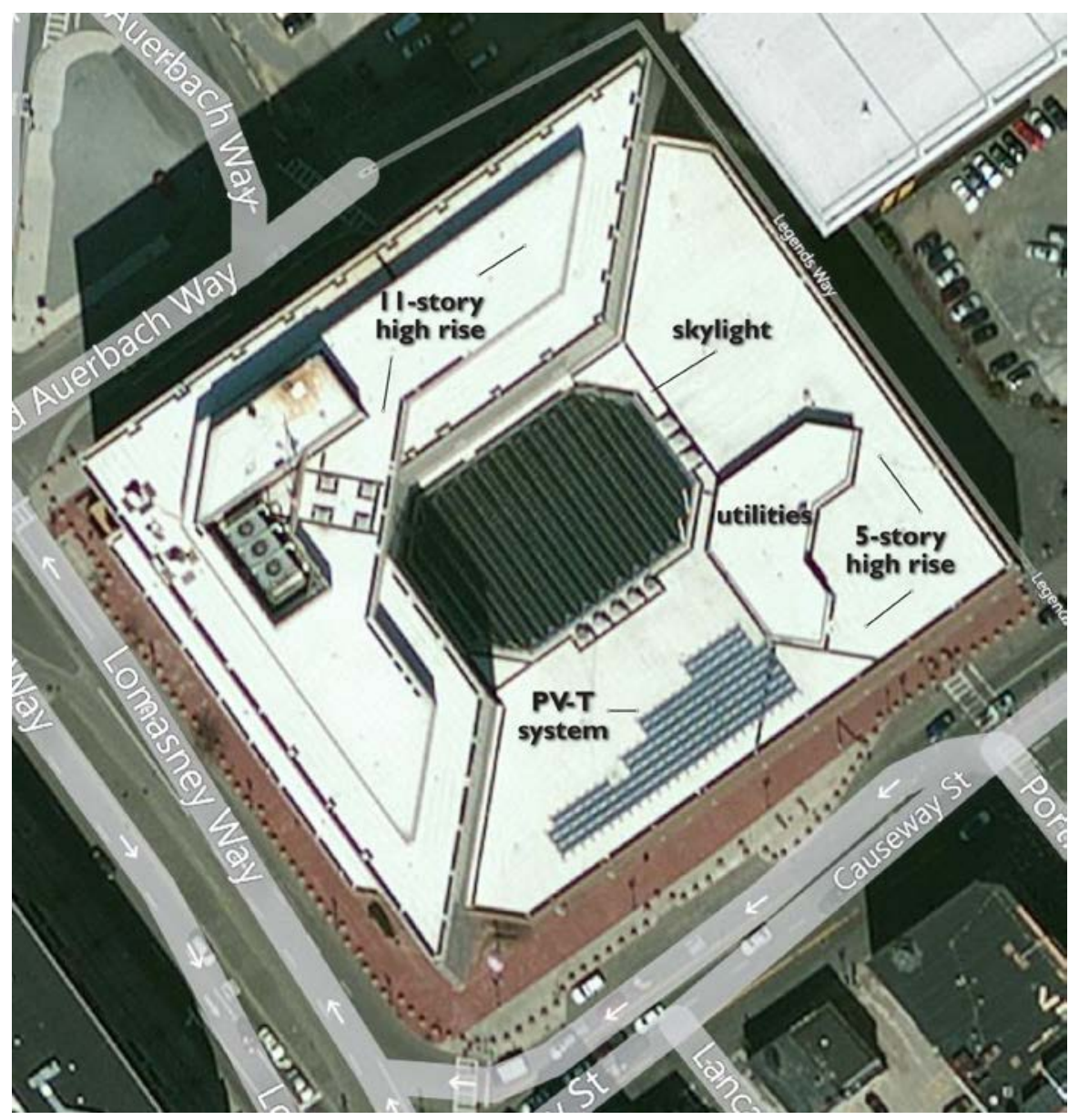

Figure 10. Aerial image of O'Neill Federal Building rooftop

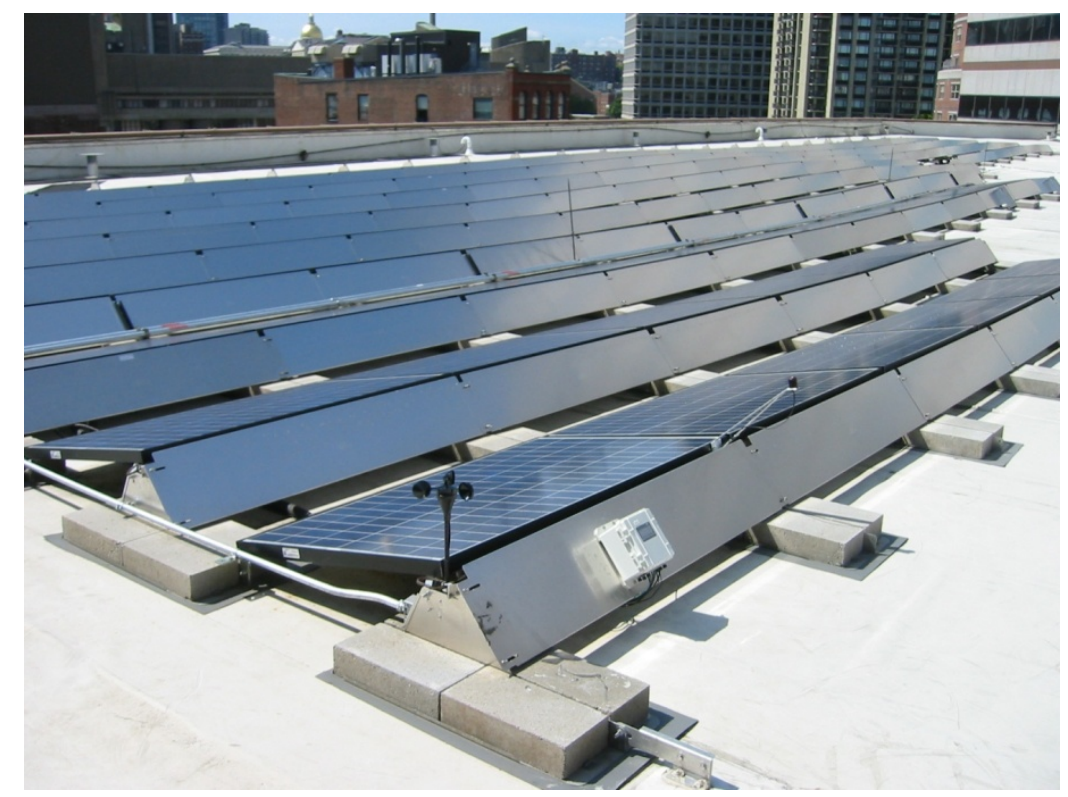

Figure 11. O'Neill Federal Building PV-T system facing approximately south 
The entire PV array consists of two sub arrays of 75 modules each (150 modules total). Each sub array consists of five strings of 15 modules. The PV panels consist of multi-crystalline silicon PV panels. The panels are rated at 210 watts and have an electrical efficiency of $13.4 \%$. The PV array utilizes a ballasted mounting system and has a tilt angle of 11 degrees. The azimuth angle of the array is approximately 145 degrees, and the system experiences late afternoon shading from the upper section of the facility, with a weighted average annual solar access of $80 \%$. A one-line electrical diagram is provided in Figure 12.

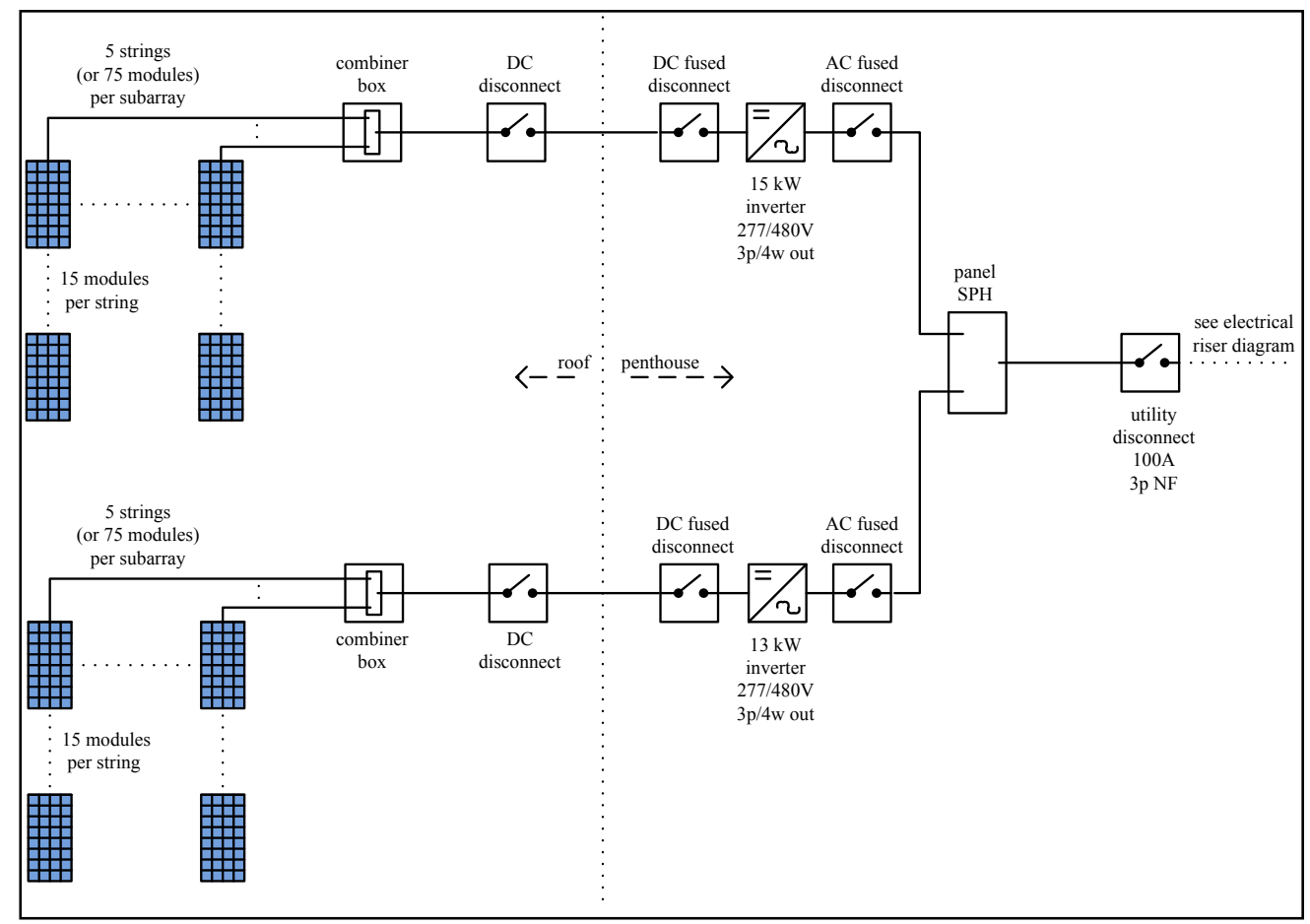

Figure 12. O'Neil Federal Building PV-T system electrical diagram

The array has a tilt angle of $11^{\circ}$. During the installation of the PV system, the modules were binned to improve the overall performance of the electrical system by reducing mismatch losses. The modules have a performance rating of $-0 /+5$ watts of the rated capacity, which means that the top-rated modules have initial power ratings that are higher than the nameplate rating by as much as 5 watts. The PV modules were factory-tested and a specific power rating was identified for each panel. The higherperforming 75 modules are connected to a 15-kW inverter (rated at $15 \mathrm{kWAC}$ ) and the lower-performing modules are connected to a 13-kW inverter (rated at $12.3 \mathrm{kWAC}$ ). The inverters have a peak efficiency of 94.5\%. Figure 13 shows the inverters mounted in the penthouse with the DC and AC disconnects attached to the sides of the inverters. 


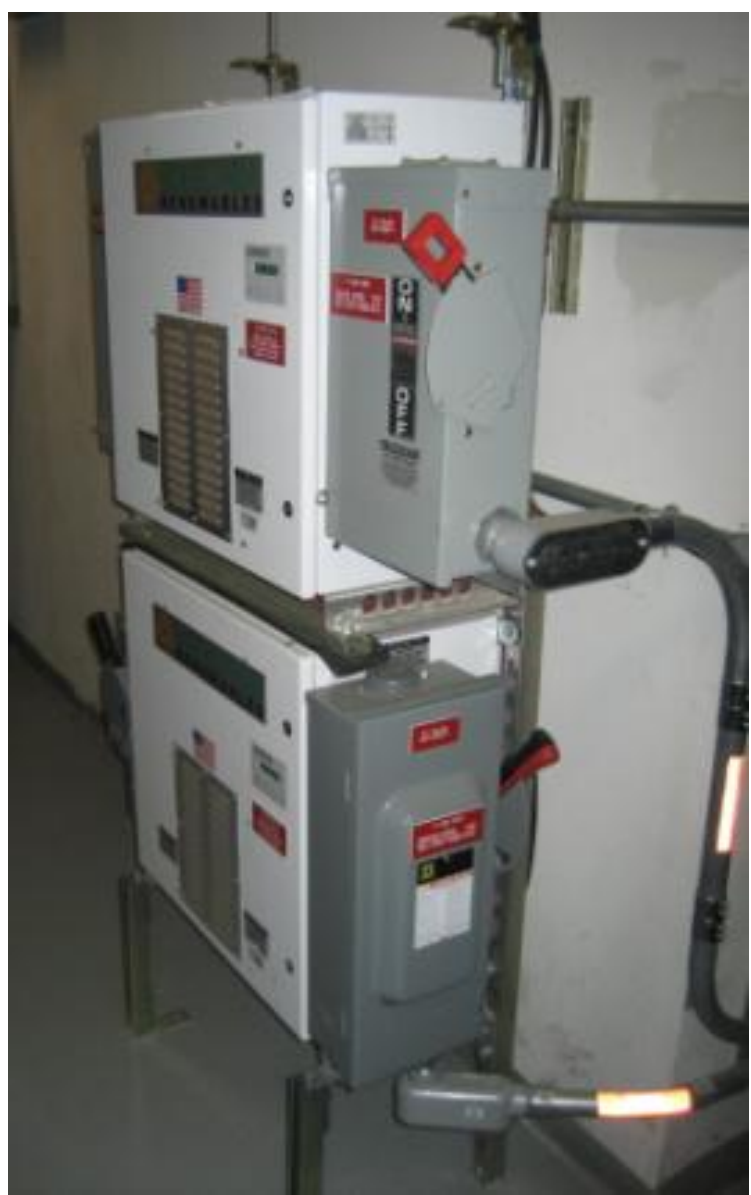

Figure 13. Two inverters and disconnects

The thermal system is comprised of 144 units that are attached to the back of the PV panels. The thermal system on the O'Neill Federal Building consists of 3 loops, each with 48 thermal collectors and 160 gallons of storage in two 80-gallon tanks, with a total of 144 collectors and 480 gallons of storage. The total active collector area for the system is rated at $1,472.5 \mathrm{ft}^{2}$. Of the $150 \mathrm{PV}$ panels, 144 have solar thermal collectors installed on the back of the panel, and 6 PV panels have no thermal backing. Figure 14 shows the placement of the three main hot water loops, shown in yellow, purple, and blue, with the 6 PV modules without solar thermal backing shown in orange. 


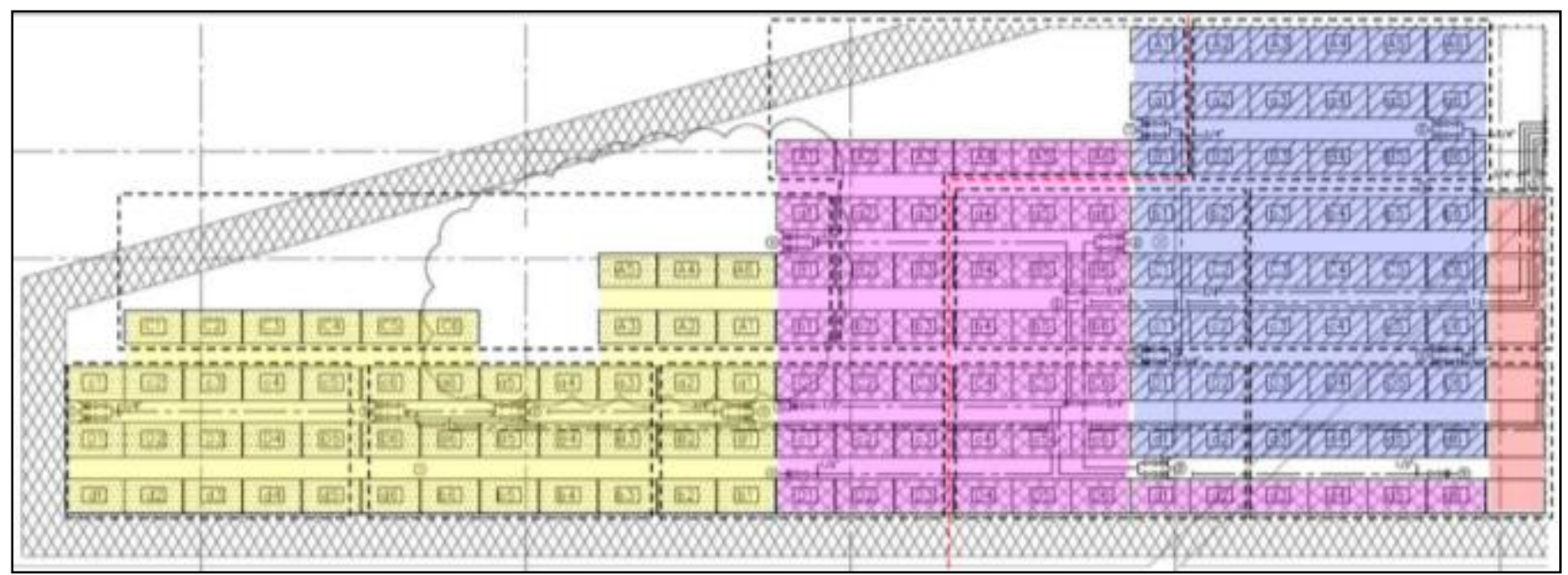

Figure 14. PV-T System solar thermal loops and 6 PV panels without solar thermal

The three solar thermal loops have 6 collectors per string, as shown in Figure 15. The heat transfer fluid, propylene glycol, is coldest at the inlet to the first series of collectors. The average temperature gain across a panel is rated at $5^{\circ} \mathrm{F}$, but depends on the panel temperature, ambient temperature, wind speed, and heat transfer fluid flow rate. As the heat transfer fluid flows through the string of 6 collectors, the heat transfer fluid temperature increases, with a total design temperature rise of $30^{\circ} \mathrm{F}$. The PV panels closest to the cold heat transfer fluid inlet experience the greatest cooling. There are a total of eight strings per sub array (48 panels) and a total of three sub arrays.
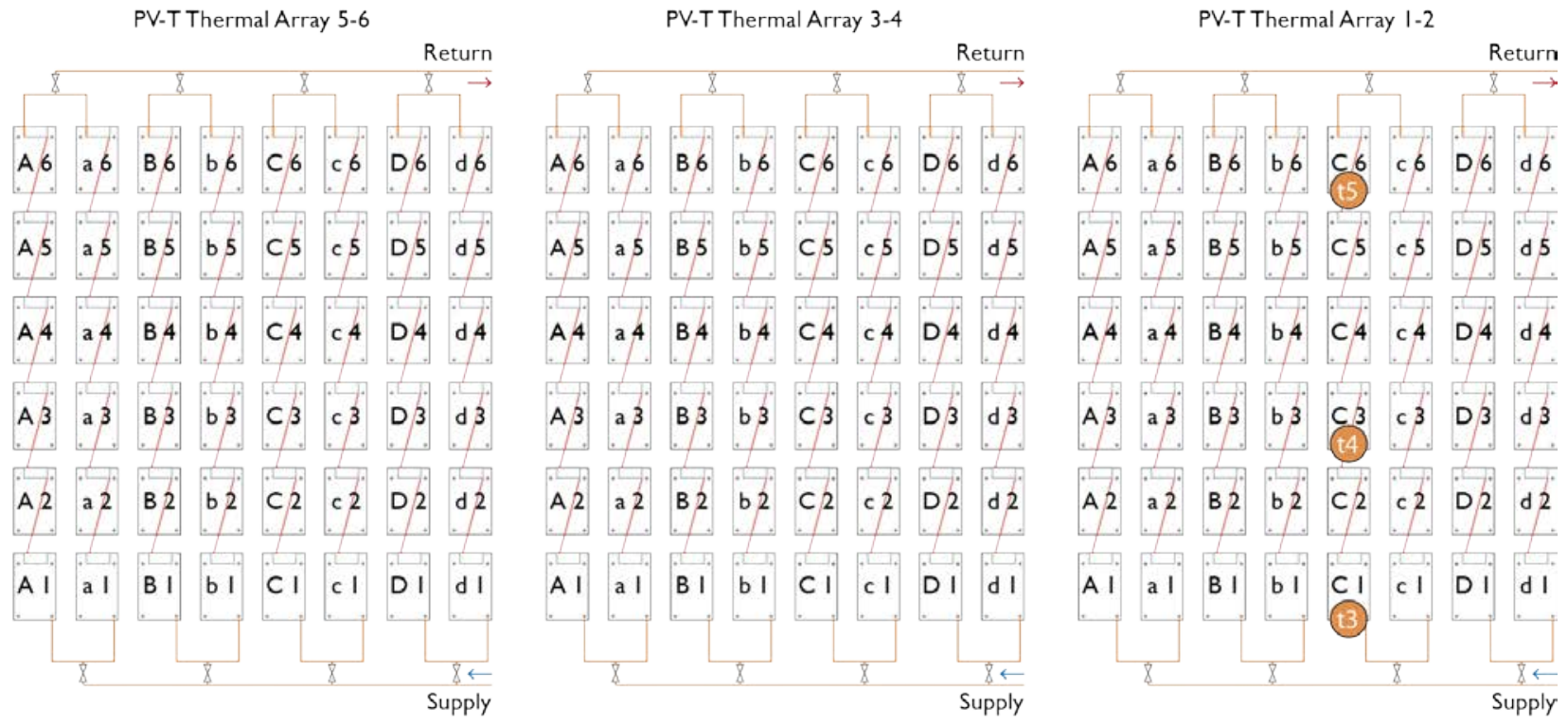

(5) thermocouple

Figure 15. Graphical representation of three solar thermal loops 
The design goal for the DHW system is to meet $20 \%$ of the building DHW load. When the solar thermal system was installed, the facility consumed approximately 4,000 to 5,000 gallons of DHW per day, and the system was sized for 5,000 gallons per day. The target design temperature of the DHW tanks is $110^{\circ} \mathrm{F}$. The DHW system provides hot water for two hot water loads:

- $\quad$ Low-rise restrooms, which represent approximately $30 \%$ of the building's DHW load; and

- $\quad$ Cafeteria and fitness center, which represent approximately $70 \%$ of the building's DHW load.

Since the equipment was installed, the thermal DHW load has been reduced due to a new dishwashing system that has reduced the DHW load to around 1,000 GPD.

The system is intentionally designed to be undersized, i.e., to include more storage than would commonly be used for the given collector output. Therefore, the system will deliver cooler water to the collectors, keeping the PV panels cooler. The collector loop heat exchangers are at the bottom of each of the storage tanks and are double walled, to meet GSA safety specifications. A representative storage tank is shown in Figure $16 .{ }^{15}$

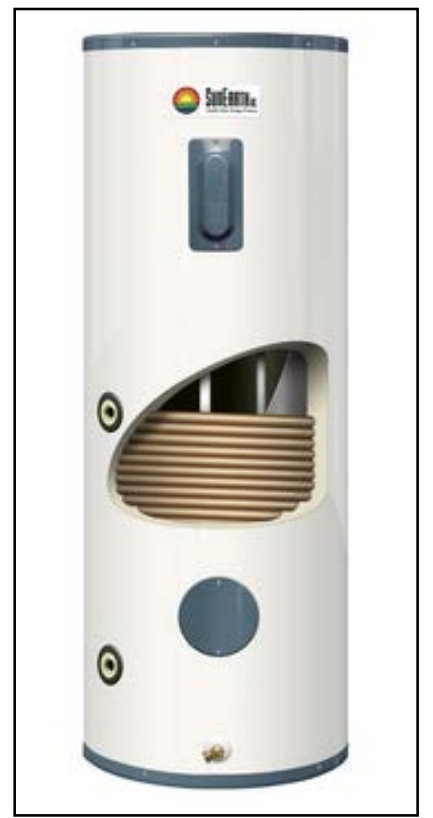

Figure 16. Solar water heating storage tank with wrap-around heat exchanger

The heat transfer fluid is propylene glycol. The storage tanks and heat exchangers are installed in series. The PV-T system installed in Boston uses a differential controller that activates the pumps once the temperature difference between the collector and tank is greater than $15^{\circ} \mathrm{F}$.

\footnotetext{
${ }^{15}$ SunEarth Inc, Solar Storage Tanks Graphic, http://www.sunearthinc.com/SolarTanks.html
} 


\section{Summary Findings and Conclusions}

\section{A. Overall Technology Assessment at Demonstration Facility}

The advantages of the PV-T technology installed in Boston are associated with the ability to install a PV and solar thermal system in the same footprint, the ability to simultaneously increase PV electrical production, and federal requirement to meet $30 \%$ of hot water loads with solar thermal loads that provide a nice fit for the technology.

The primary disadvantage of the technology is associated with the lower thermal efficiencies, which require greater surface area to provide an equivalent amount of solar thermal energy. Ultimately, the total system costs need to come in at a fraction of the costs of traditional solar thermal systems to be competitive.

Because of conflicts in the installation and commissioning of the PV-T system, the M\&V process did not deliver definitive results. However, it did provide valuable lessons learned and best practices. Modeling, based on ideal PV-T system design, provided information on where the technology could be most suitably deployed.

\section{B. Ideal System Design Used for Modeling}

The lessons learned that were identified at the demonstration in Boston were incorporated into an "ideal system" design in order to understand how the system would perform in future commercial installations. The ideal system was modeled per the manufacturer's recommendations using TRNSYS to model the solar thermal system and SolOpt to model the impacts of panel cooling on PV production. The basic system characteristics of the ideal system are outlined below.

\section{System Characteristics}

- 48 solar thermal collectors installed on the back of typical crystalline silicon PV panels

- Sub array consist of three panels in series (string), and 16 strings in parallel

- Flow rate per string 0.5 gallons/minute

- 480 gallons of storage

- Case \#1: storage tank modeled with an immersed heat exchanger

- Case \#2: storage tank modeled with an external plate and frame heat exchanger

- Typical Office building draw profile

- 1,300 gallons/day on weekdays and 0 gallons/day on weekend

- 150-Watt circulation pump

- Standalone boiler provides supplementary heating (electric boiler)

\section{Control System}

- Tank temperature set point $125^{\circ} \mathrm{F}$

- Mixing valve set point temperature $120^{\circ} \mathrm{F}$

- Pump turns on when panel temp is $15^{\circ} \mathrm{F}$ hotter than tank and turn off when tank is within $4{ }^{\circ} \mathrm{F}$ of set point

A complete list of input parameters are outlined in Table 3. 
Table 3 -Key Input Parameters for the Solar Thermal System

\begin{tabular}{||l|c|l||}
\hline \multicolumn{3}{|c||}{ Ideal Commercial PV-T System } \\
\hline Variable & \multicolumn{2}{|c||}{ Collector Array } \\
\hline PV Module Area & 16.9 & $\mathrm{ft}^{2}$ \\
\hline Number in Series & 3 & - \\
\hline Number of Modules & 48 & - \\
\hline Array Area & 811.17 & $\mathrm{ft}^{2}$ \\
\hline Tilt angle & 45 & Deg \\
\hline Azimuth & 0 & Deg \\
\hline PV efficiency & 13 & $\%$ \\
\hline A10 & 0.337 & - \\
\hline A10 & 0.00756 & - \\
\hline A20 & 10.1245 & - \\
\hline A21 & 0.02415 & - \\
\hline Variable & \multicolumn{2}{|c||}{ Piping } \\
\hline Pipe length & 100 & $\mathrm{ft}$ \\
\hline Pipe diameter & 0.8 & in \\
\hline Pipe insulation thickness & 0.5 & in \\
\hline Insulation conductivity & 0.02 & Btu/h-ft-F \\
\hline Variable & \multicolumn{2}{|c||}{ Storage Tank } \\
\hline Tank Volume & 480 & gal \\
\hline Tank height & 6.56 & ft \\
\hline Insulation k value & 0.23 & Btu/h-ft-F \\
\hline Insulation thickness & 2.5 & in \\
\hline Tank U value & 0.069 & Btu/h-ft2-f \\
\hline Number of nodes & 20 & - \\
\hline Variable & Circulation System \\
\hline Delta T to Activate Pump & 15 & $\mathrm{~F}$ \\
\hline Delta T to Turn Off Pump & 4 & $\mathrm{~F}$ \\
\hline Pump power & 150 & W \\
\hline Solar loop flow rate & 8 & gpm \\
\hline \hline
\end{tabular}

\section{Thermal Model}

The ideal solar thermal system was modeled in TRNSYS. TRNSYS (Transient System Simulation Tool) graphically based software environment is used to simulate the behavior of transient systems. TRNSYS is a time-series hourly simulation program that can simulate the performance of photovoltaic and SHW systems using TYM2 or TMY3 weather data. TMY2 and TMY3 weather datasets are assembled as 15year average hourly weather data sets for a specific location. TRNSYS is the most accurate and robust 
hourly simulation program for solar thermal systems and the TRNSYS model is available upon request. ${ }^{16}$ The thermal model constructed for the PV-T system is shown in Figure 17. The solar loop is shown in red, the potable water lines are shown in blue, and the boiler loop is shown as magenta.

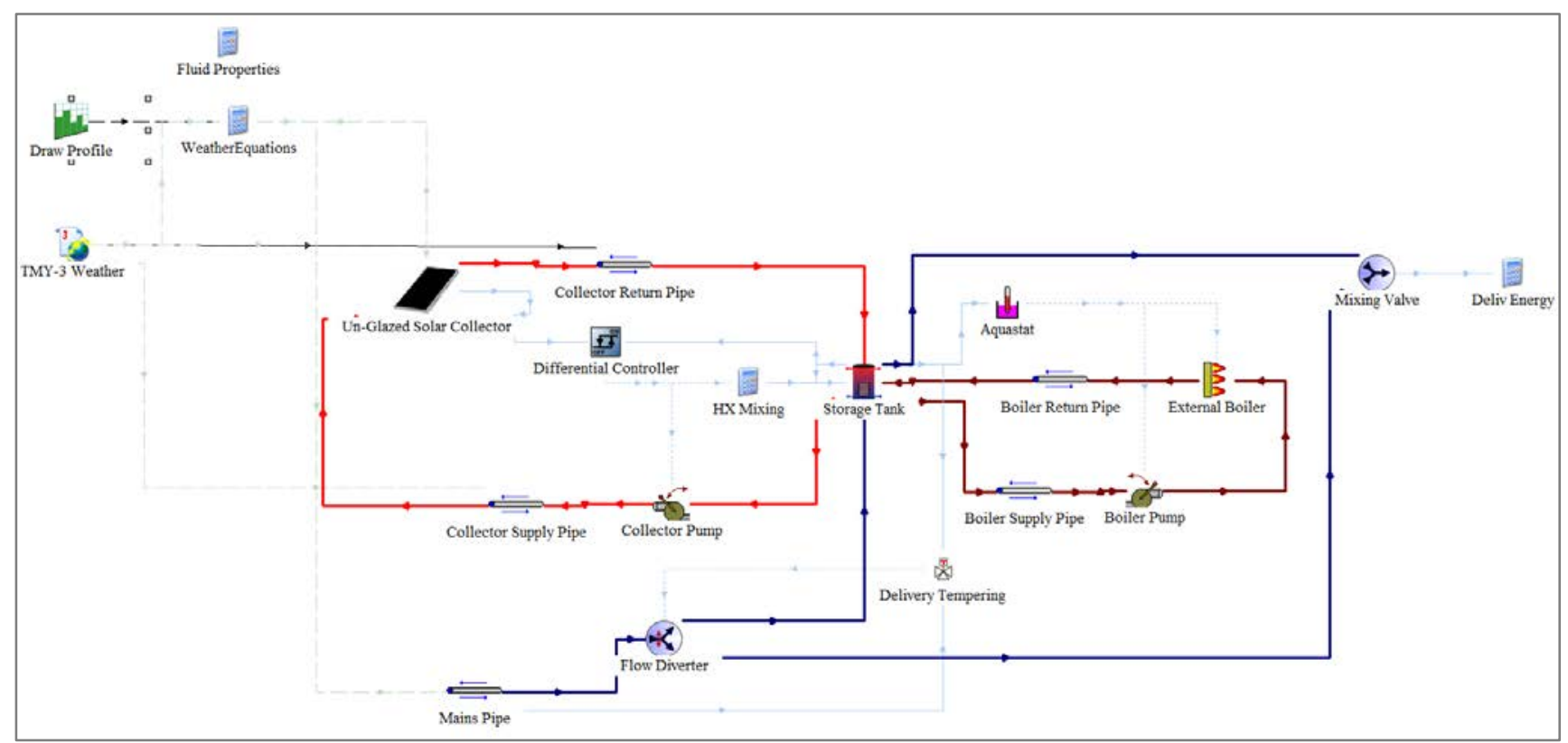

Figure 17 - Thermal Model. The solar loop is shown in red, and the water loops are shown in blue. The boiler loop is shown as magenta.

The collectors here are modeled as in ISO9806/SRCC OG100. The collector efficiency equation is given as:

$\eta_{\text {coll }}=A_{1,0}\left(1-A_{1,1} V_{\text {wind }}\right) K(\theta)-A_{2,0}\left(1+A_{2,1} V_{\text {wind }}\right) / I_{\text {net }}$

where $A_{i, j}$ are coefficients determined by the OG100 test, $V_{\text {wind }}$ is the wind velocity, $K(\theta)$ is the effective incidence angle modifier, and $I_{n e t}$ is the net radiation. $I_{\text {net }}$ is calculated as:

$I_{\text {net }}=I_{\text {sun }}-(\varepsilon / \alpha)_{\text {absorber }} I_{\text {net, }, R}$, where $I_{\text {net, }, R}=$ net long-wave infrared exchange with sky $=\sigma\left(T_{a m b}{ }^{4}-T_{\text {sky }}{ }^{4}\right)$.

$\mathrm{T}_{\text {sky }}$ is the effective black body sky temperature, as calculated using the methods of Martin-Berdahl (2). $I_{\text {net,IR }}$ goes to zero under $100 \%$ cover, and can be up to $150 \mathrm{~W} / \mathrm{m}^{2}$ under clear skies with low humidity.

The incident angle modifier function as supplied by SRCC is shown in Figure 18. The values are impossible for a flat plate PV with a glass or polymer cover sheet. The IAMs shown here are very typical for an evacuated tube collector without a back reflector; despite assurances from SRCC that these are the right values, the data was not used because the curves are not physically possible for flat plate collector systems. Rather, the IAMs from other similar PV/T systems were examined, which showed very flat behavior out to about 60 degrees, where it began to drop off to zero at 90 degrees. The function adopted here is also shown in Figure 18.

${ }^{16}$ http://www.trnsys.com 


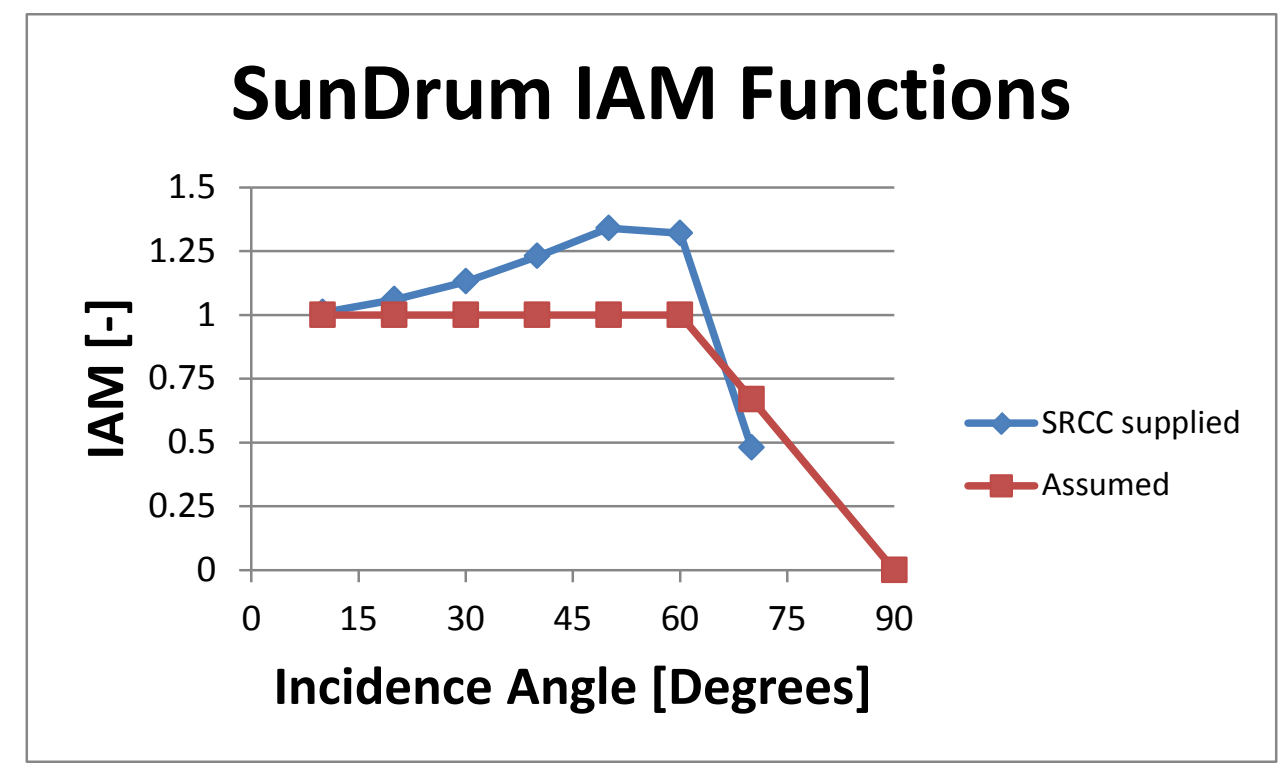

Figure 18 Incidence angle modifier function.

Note: The SRCC supplied curve is the data on the certification report, and the assumed curve was taken from similar systems and used here.

\section{System Metrics}

$\mathrm{Q}_{\text {solar }}$ is the energy delivered by the solar system to the downstream (unspecified) auxiliary and the water heating loads:

$\mathrm{Q}_{\text {solar }}=\dot{\mathrm{m}} \mathrm{c}_{\mathrm{p}}\left(\mathrm{T}_{\text {out,tank }}-\mathrm{T}_{\text {mains,in }}\right)$

$\mathrm{Q}_{\text {solar,net }}$ is the net energy including parasitic power consumed (only the pump/controller here):

$Q_{\text {solar,net }}=Q_{\text {solar }}-Q_{\text {parasitic }}$

Related metrics are the collector efficiency, the system efficiency (which includes pipe and tank losses), and the solar fraction $F_{\text {sol }}=Q_{\text {solar, net }} / Q_{\text {load }}$, where $Q_{\text {load }}=\dot{m} c_{p}\left(T_{\text {set }}-T_{\text {mains,in }}\right)$.

\section{System Parameters}

The SRCC thermal collector test report is given in Appendix A. It was tested without the PV active. Subsequent changes to OG100 have clarified that the PV must be switched on when testing for thermal performance. This rule makes sense because the PV will always be operative during normal operation, and when PV is on irradiance that would have been thermalized it is instead used to promote electron excitation and electrical power. Thus, the unit produces less thermal energy than when the PV is off. Because the PV was off during the thermal collector test, the PV energy during normal operation must be subtracted from the available energy. Here, NREL subtracted the PV energy production directly from the incidence, because that energy is never thermalized. That is,

$\mathrm{I}_{\text {sun, effective incidence }}=\left(1-\eta_{\mathrm{PV}}\right) \mathrm{I}_{\text {sun,incident }}$ 


\section{Draw Profile}

The draw profile used is shown in Figure 19. The water draw is constant from 7AM to 6 PM for weekdays, and is zero for weekends. The NREL analysis did not use the more complex ASHRAE office building draw profile, which has some variation throughout the workday, because the large storage capacity leads to the exact profile of usage being of no relevance; only the daily total volume is significant. NREL thus chose the simpler but equivalent draw profile of Figure 19 - Water draw time profile. The draw is a constant value on weekdays from $7 \mathrm{AM}$ to $6 \mathrm{PM}$, and is set to zero otherwise. The total daily draw volume was set to $1,300 \mathrm{gal} /$ day on weekdays, and $0 \mathrm{gal} /$ day on weekends. The year starts with Monday, and holidays are not considered.

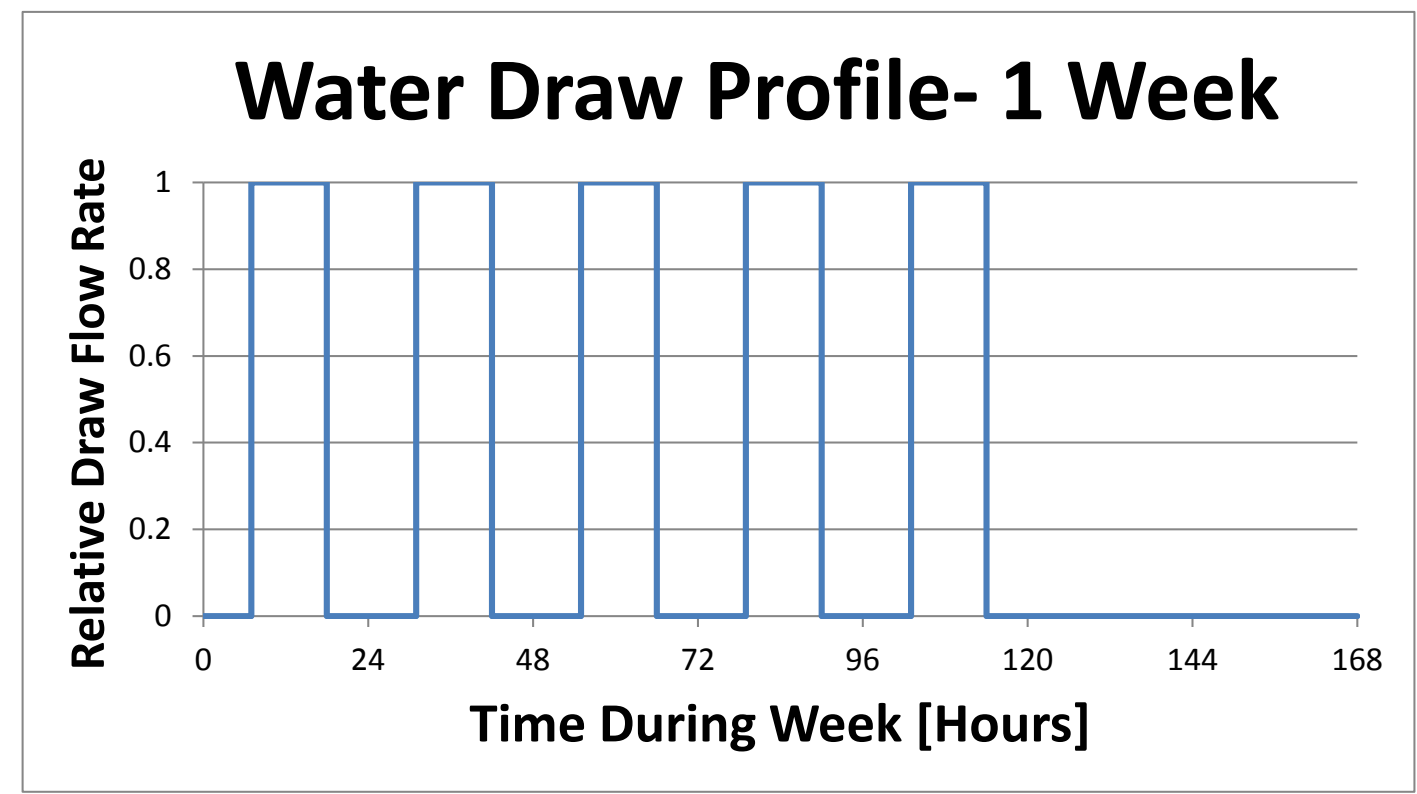

Figure 19 - Water draw time profile. The draw is a constant value on weekdays from 7 AM to 6 PM, and is set to zero otherwise.

The weather files used are TMY3 files. The variables used include the solar beam/diffuse/total on horizontal, the ambient temperature, the humidity, the cloud cover, and the wind velocity. No account was taken for presence of snow cover, as this field is not present in TMY3 weather files. The humidity and cloud cover are used to compute the net sky infrared flux. The weather sites chosen are for Boston, MA; Dagget, CA; Denver, CO; Honolulu, HA; Phoenix, AZ; and Portland, OR.

\section{Results}

The total domestic hot water load, heat into the tank, and total solar energy are provided in Figure 20. The total solar energy term is the total energy into the tank minus the solar loop pumping energy. As expected, the energy delivered is larger in the sunnier climates like Phoenix and Denver, and lower in the more cloudy climates like Portland and Boston. 


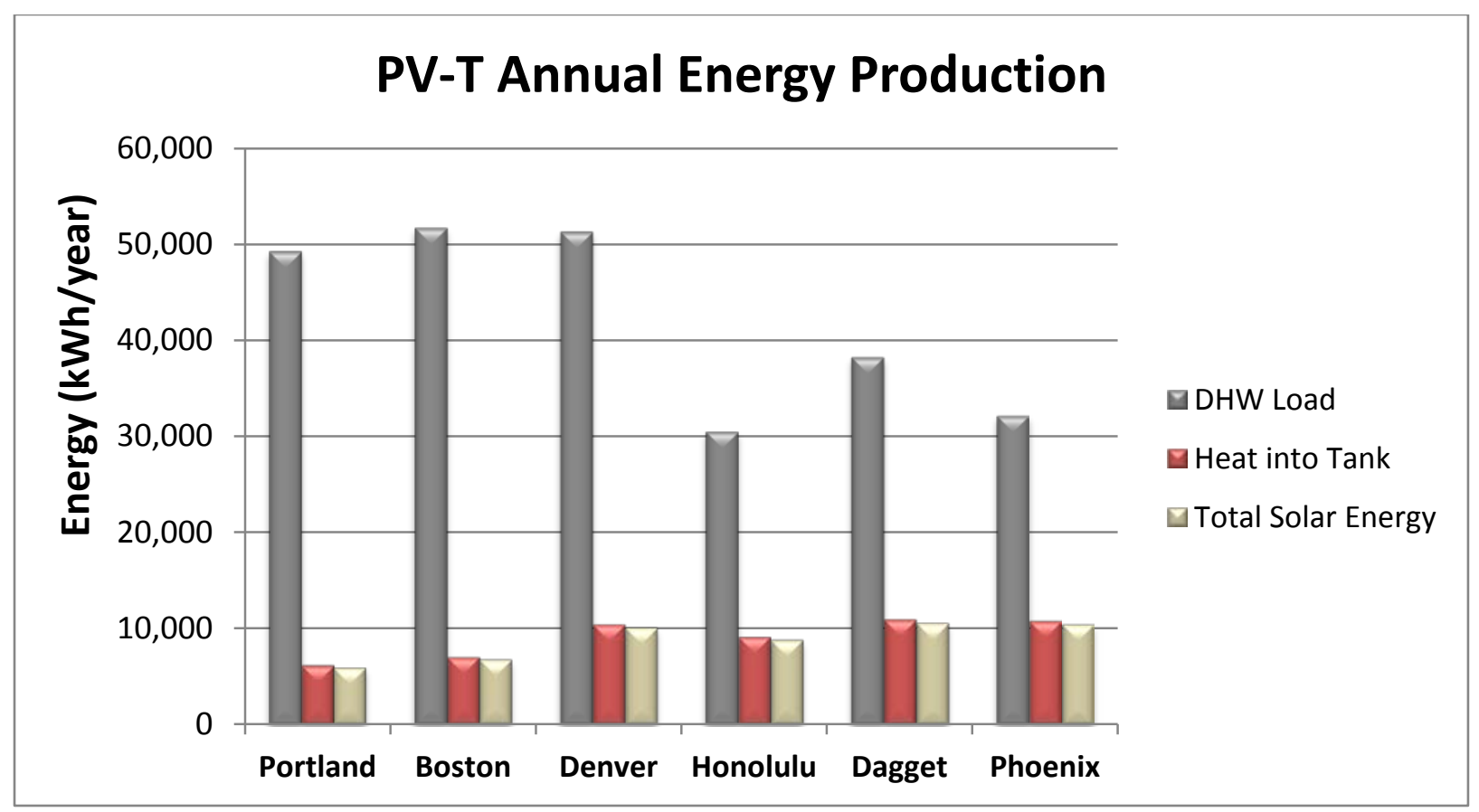

Figure 20 -PV-T Annual Energy Production

Two cases were run for the ideal system, one case with an immersed heat exchanger and one case for an external heat exchanger. The solar thermal fraction and annual solar thermal collector efficiency are provided in Figure 21 and Figure 22. The solar thermal fraction (percent of domestic hot water load met by the solar thermal system) varies from $10 \%$ to $26 \%$. The annual average collector efficiency ranges from $5.7 \%$ to $7.6 \%$ depending on location.

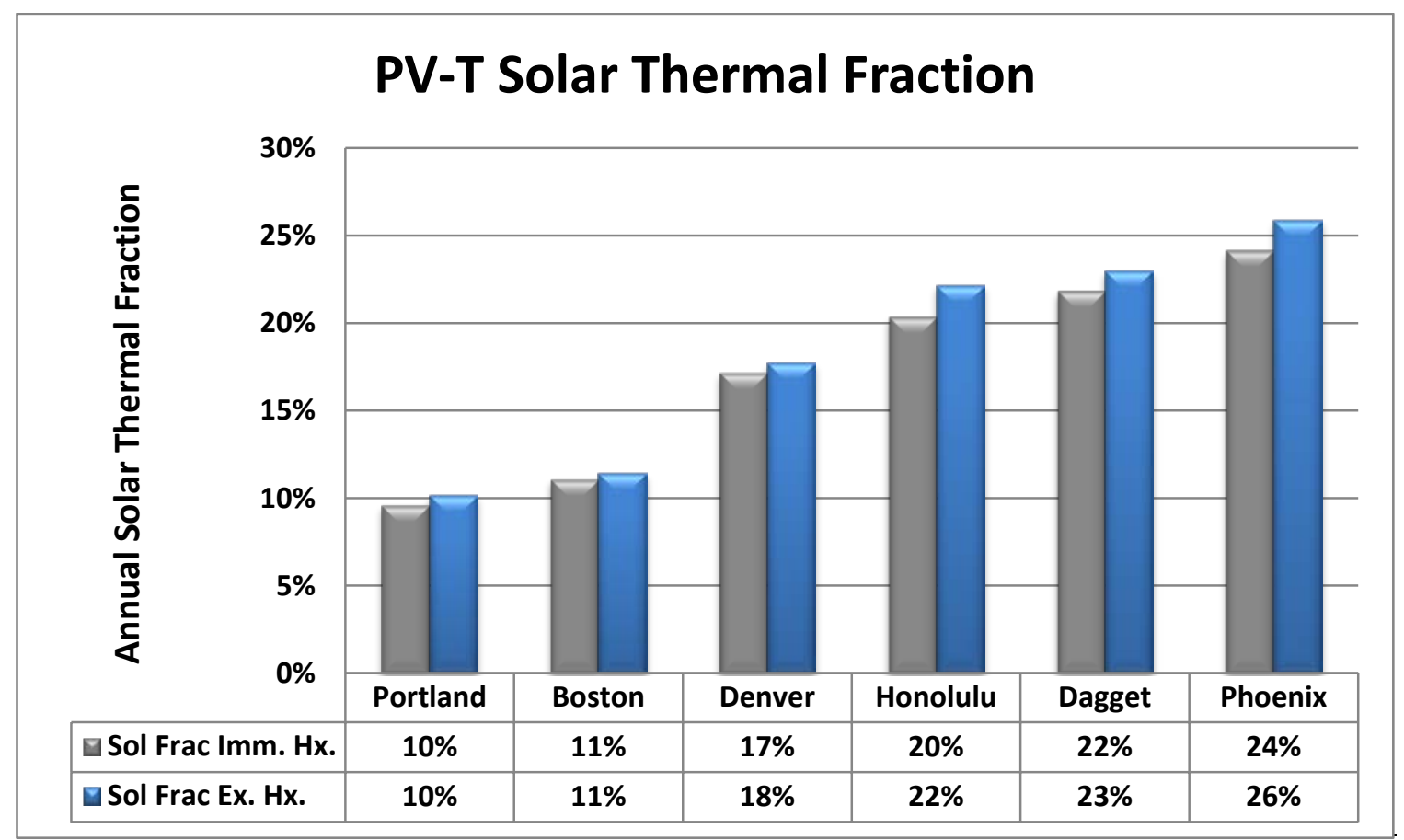

Figure 21 -PV-T Solar Thermal Fraction 


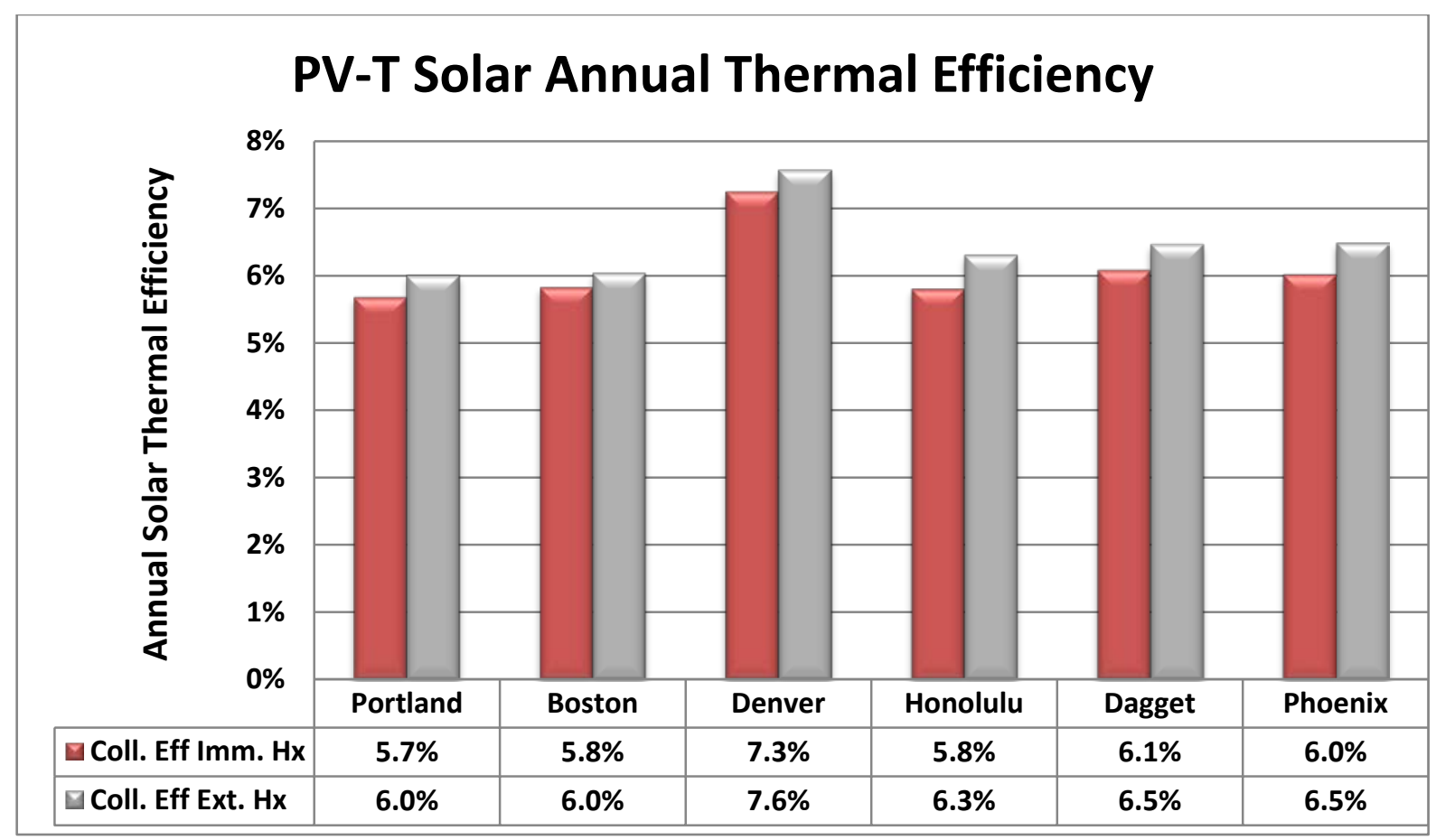

Figure 22 -PV-T Solar Thermal Efficiency

The thermal collector manufacturer provided revised installed cost estimates that estimated the installed cost of the solar thermal portion of the system at $\$ 57,223$ (Table 4).

Table 4 -Key Input Parameters for the Solar Thermal System

\begin{tabular}{||l|c|c||}
\hline \multicolumn{3}{|c||}{ Installed Costs } \\
\hline PV-T System Components \& Labor & Price & $\begin{array}{c}\text { Dealer } \\
\text { Price }\end{array}$ \\
\hline SDK400 kit & $\$ 43,200$ & $\$ 32,400$ \\
\hline Collector Installation Labor & $\$ 1,440$ & $\$ 1,080$ \\
\hline $\begin{array}{l}\text { Solar Storage Tank/w heat } \\
\text { exchanger }\end{array}$ & $\$ 4,800$ & $\$ 3,600$ \\
\hline External H/E (Pool) & $\$ 400$ & $\$ 300$ \\
\hline Plumber (Tank Connections) & $\$ 2,100$ & $\$ 1,575$ \\
\hline Plumber (HE Connections) & $\$ 1,400$ & $\$ 1,050$ \\
\hline PEX + cladding & $\$ 400$ & $\$ 300$ \\
\hline PEX Installation labor & $\$ 400$ & $\$ 300$ \\
\hline Contingency (2\%) & $\$ 3,083$ & $\$ 2,312$ \\
\hline Total PV-T Components \& Labor & $\$ 57,223$ & $\$ 42,917$ \\
\hline
\end{tabular}


The revised installed cost estimates were then used to calculate a simple payback in each location (Table 5 and Table 6). The simple payback was calculated using blended electric rates for the commercial sector for each state from the Energy Information Administration (EIA). ${ }^{17}$ The city cost adjustment multiplier comes from the construction estimation database RSMeans and is applied to the installed cost estimate for each location. ${ }^{18}$ The simple payback does not include any local or federal incentives and is a nonincentivized payback.

Table 5 -Energy Savings and Economics for Immersed Heat Exchanger Case

\begin{tabular}{||l|c|c|c|c|c|c||}
\hline City & $\begin{array}{c}\text { Electricity } \\
\text { Rate } \\
\mathbf{( \$ / k W h )}\end{array}$ & $\begin{array}{c}\text { City Cost } \\
\text { Adjustment } \\
\text { Multiplier }\end{array}$ & $\begin{array}{c}\text { Solar } \\
\text { Energy } \\
\text { Production } \\
\mathbf{( k W h / y r )}\end{array}$ & $\begin{array}{c}\text { Annual } \\
\text { Cost } \\
\text { Savings (\$) }\end{array}$ & $\begin{array}{c}\text { Installed } \\
\text { Cost (\$) }\end{array}$ & $\begin{array}{c}\text { Simple } \\
\text { Payback } \\
\text { (yrs) }\end{array}$ \\
\hline Portland, OR & 0.0868 & 0.99 & 5,934 & $\$ 515$ & $\$ 56,765$ & 110 \\
\hline Boston, MA & 0.1476 & 1.17 & 5,934 & $\$ 876$ & $\$ 67,065$ & 77 \\
\hline Denver, CO & 0.1083 & 0.94 & 10,063 & $\$ 1,090$ & $\$ 53,961$ & 50 \\
\hline Honolulu, HI & 0.3454 & 1.17 & 8,780 & $\$ 3,033$ & $\$ 67,123$ & 22 \\
\hline Daggett, CA & 0.1813 & 1 & 10,529 & $\$ 1,909$ & $\$ 56,994$ & 30 \\
\hline Phoenix, AZ & 0.105 & 0.89 & 10,384 & $\$ 1,090$ & $\$ 50,757$ & 47 \\
\hline
\end{tabular}

Table 6 -Energy Savings and Economics for External Heat Exchanger Case

\begin{tabular}{|c|c|c|c|c|c|c|}
\hline City & $\begin{array}{c}\text { Electricity } \\
\text { Rate } \\
\text { (\$/kWh) }\end{array}$ & $\begin{array}{l}\text { City Cost } \\
\text { Adjustment } \\
\text { Multiplier }\end{array}$ & $\begin{array}{c}\text { Solar } \\
\text { Energy } \\
\text { Production } \\
\text { (kWh/yr) } \\
\end{array}$ & $\begin{array}{c}\text { Annual } \\
\text { Cost } \\
\text { Savings (\$) }\end{array}$ & $\begin{array}{c}\text { Installed } \\
\text { Cost (\$) }\end{array}$ & $\begin{array}{c}\text { Simple } \\
\text { Payback } \\
\text { (yrs) }\end{array}$ \\
\hline Portland, OR & 0.0868 & 0.99 & 6,349 & $\$ 551$ & $\$ 56,765$ & 103 \\
\hline Boston, MA & 0.1476 & 1.17 & 5,934 & $\$ 876$ & $\$ 67,065$ & 77 \\
\hline Denver, CO & 0.1083 & 0.94 & 10,605 & $\$ 1,149$ & $\$ 53,961$ & 47 \\
\hline Honolulu, HI & 0.3454 & 1.17 & 9,614 & $\$ 3,321$ & $\$ 67,123$ & 20 \\
\hline Daggett, CA & 0.1813 & 1 & 11,269 & $\$ 2,043$ & $\$ 56,994$ & 28 \\
\hline Phoenix, AZ & 0.105 & 0.89 & 11,247 & $\$ 1,181$ & $\$ 50,757$ & 43 \\
\hline
\end{tabular}

The energy savings and economics are slightly better with the external heat exchanger.

\footnotetext{
${ }^{17}$ Energy Information Administration, http://www.eia.gov

${ }^{18}$ RS Means, http://rsmeans.reedconstructiondata.com
} 


\section{Modeled Increase in PV Production}

It also is necessary to account for the synergies that exist from simultaneously cooling the PV modules. The PV system was modeled using SolOpt in the same 6 locations. The PV system production is calculated in SolOpt using panel properties from a database of panel types and manufacturers. This subset of panel options was taken from the SAM database of panels. The production calculation algorithms are based on an efficiency model. ${ }^{19}$ The PV module output is based on the temperatureadjusted efficiency of the module. The cell temperature of the module is calculated on an hourly basis, and the efficiency of the module is adjusted accordingly. ${ }^{20}$

The efficiency of the PV panel is calculated with the Equation 5.

$$
\begin{gathered}
\text { Equation 5: PV panel efficiency } \\
\text { Efficiency }=E F F_{\text {ref }} *\left(1+\operatorname{Temp}_{\text {Co }} *\left(T_{\text {ref }}-T_{\text {cell }}\right)\right)
\end{gathered}
$$

Where

$$
\begin{array}{ll}
\text { Efficiency } & =\text { PV panel efficiency } \\
\text { EFF }_{\text {ref }} & =\text { reference panel efficiency } \\
T_{\text {Temp }} & =\text { panel power temperature coefficient } \\
T_{\text {ref }} & =\text { reference temperature }\left(77^{\circ} \mathrm{F}\right) \\
\mathrm{T}_{\text {cell }} & =\text { calculated cell temperature }
\end{array}
$$

The cell temperature is calculated on an hourly basis in SolOpt using Equation 6

Equation 6: PV cell temperature

$$
T_{\text {Cell }}=T_{O A}+\left(\text { Solar }_{\text {insolation }} * \frac{\left(T_{O p}-T_{\text {ref }}\right)}{R e f_{\text {insolation }}}\right) *\left(1-E F F_{\text {ref }}\right)
$$

Where

$$
\begin{array}{ll}
\mathrm{T}_{\text {cell }} & =\text { cell temperature } \\
\mathrm{T}_{\text {oa }} & =\text { outside air temperature } \\
\mathrm{T}_{\mathrm{op}} & =\text { nominal operating temperature } \\
\text { Cell }_{\mathrm{Temp}} & =\text { calculated cell temperature } \\
\text { Solar }_{\text {insolation }} & =\text { solar insolation } \\
\text { Ref }_{\text {insolation }} & =\text { reference insolation } \\
\mathrm{Eff}_{\text {ref }} & =\text { reference panel efficiency }
\end{array}
$$

\footnotetext{
${ }^{19}$ Menicucci, D.F. "Photovoltaic Array Performance Simulation Models." Photovoltaics and Insolation Measurements Workshop, Vail, CO, U.S.A., June 30 - July 3, 1985. Albuquerque, NM: Sandia National Laboratories, 1985.

${ }^{20}$ Fuentes, M. K. “A Simplified Thermal Model of Photovoltaic Modules." SAND85-0330 Albuquerque, NM: Sandia National Laboratories, 1985.
} 
The SolOpt code was modified to analyze the effects of panel temperature on an hourly basis at each location. The code was modified to reduce the cell temperature by $3^{\circ} \mathrm{F}, 5^{\circ} \mathrm{F}, 10^{\circ} \mathrm{F}$, and $20^{\circ} \mathrm{F}$ for every hour that the system is producing electricity. This provides a conservative estimate of increased electricity production. In real life an actual installation would have periods of time that the solar thermal pumps are not activated or would need to warm up before the control signal turns on the pumps, and thus the PV panels would not experience a consistent reduction in panel temperature each hour of the year. The increase in PV output is fairly constant from one location to the next, as shown in Figure 23.

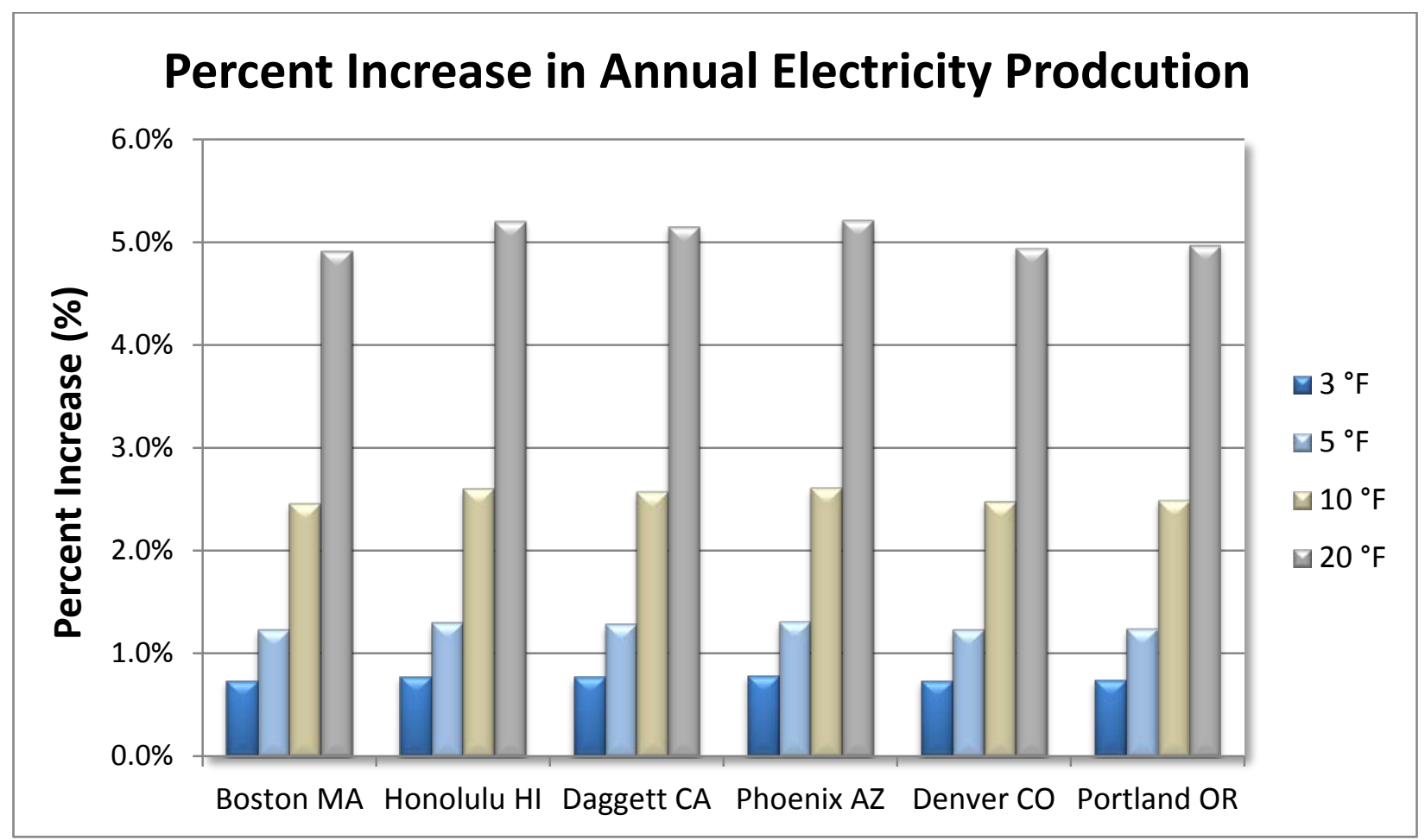

Figure 23. Percent increase in annual production

The average percent increase in annual electricity production across each climate zones is $0.8 \%$ at $3^{\circ} \mathrm{F}$, $1.3 \%$ at $5^{\circ} \mathrm{F}, 2.5 \%$ at $10^{\circ} \mathrm{F}$, and $5.1 \%$ at $20^{\circ} \mathrm{F}$.

NREL recalculated the simple payback for each location using the external plate and frame heat exchanger case assuming the solar thermal panels would reduce the PV panel temp $10^{\circ} \mathrm{F}$ (which is a very conservative estimate). The economics are presented in Table 7 for the non-incentivized case and for a case that includes a $30 \%$ investment tax credit (Table 8 ). 
Table 7 - Ideal PV-T System Simple Payback Including Increased PV Production

\begin{tabular}{||l|c|c|c|c|c|c||}
\hline City & $\begin{array}{c}\text { Electricity } \\
\text { Rate } \\
\mathbf{( \$ / k W h )}\end{array}$ & $\begin{array}{c}\text { City Cost } \\
\text { Adjustment } \\
\text { Multiplier }\end{array}$ & $\begin{array}{c}\text { Solar } \\
\text { Energy } \\
\text { Production } \\
\mathbf{( k W h / y r )}\end{array}$ & $\begin{array}{c}\text { Annual } \\
\text { Cost } \\
\text { Savings (\$) }\end{array}$ & $\begin{array}{c}\text { Installed } \\
\text { Cost (\$) }\end{array}$ & $\begin{array}{c}\text { Simple } \\
\text { Payback } \\
\text { (yrs) }\end{array}$ \\
\hline Portland, OR & 0.0868 & 0.992 & 6,698 & $\$ 581$ & $\$ 56,765$ & 98 \\
\hline Boston, MA & 0.1476 & 1.172 & 6,331 & $\$ 934$ & $\$ 67,065$ & 72 \\
\hline Denver, CO & 0.1083 & 0.943 & 11,063 & $\$ 1,198$ & $\$ 53,961$ & 45 \\
\hline Honolulu, HI & 0.3454 & 1.173 & 10,097 & $\$ 3,488$ & $\$ 67,123$ & 19 \\
\hline Daggett, CA & 0.1813 & 0.996 & 11,824 & $\$ 2,144$ & $\$ 56,994$ & 27 \\
\hline Phoenix, AZ & 0.105 & 0.887 & 11,783 & $\$ 1,237$ & $\$ 50,757$ & 41 \\
\hline
\end{tabular}

Honolulu $\mathrm{HI}$ and Daggett CA are the only locations (of the 6 analyzed) that have a payback period that meets the federal life cycle costing requirements and has a payback period under 40 years. Future GSA installations that can't capture the federal tax credits should focus on installations in HI with electric hot water back up tanks until other markets mature and the technology is shown to be cost effective in other locations.

Table 8 - Ideal PV-T System Simple Payback Including Increased PV Production and Federal Tax Credit

\begin{tabular}{|c|c|c|c|c|c|c|}
\hline City & $\begin{array}{c}\text { Electricity } \\
\text { Rate } \\
\text { (\$/kWh) }\end{array}$ & $\begin{array}{l}\text { City Cost } \\
\text { Adjustment } \\
\text { Multiplier }\end{array}$ & $\begin{array}{c}\text { Solar } \\
\text { Energy } \\
\text { Production } \\
\text { (kWh/yr) } \\
\end{array}$ & $\begin{array}{c}\text { Annual } \\
\text { Cost } \\
\text { Savings (\$) }\end{array}$ & $\begin{array}{c}\text { Installed } \\
\text { Cost (\$) }\end{array}$ & $\begin{array}{c}\text { Simple } \\
\text { Payback } \\
\text { (yrs) }\end{array}$ \\
\hline Portland, OR & 0.0868 & 0.992 & 6,698 & $\$ 581$ & $\$ 39,736$ & 68 \\
\hline Boston, MA & 0.1476 & 1.172 & 6,331 & $\$ 934$ & $\$ 46,946$ & 50 \\
\hline Denver, CO & 0.1083 & 0.943 & 11,063 & $\$ 1,198$ & $\$ 37,773$ & 32 \\
\hline Honolulu, HI & 0.3454 & 1.173 & 10,097 & $\$ 3,488$ & $\$ 46,986$ & 13 \\
\hline Daggett, CA & 0.1813 & 0.996 & 11,824 & $\$ 2,144$ & $\$ 39,896$ & 19 \\
\hline Phoenix, AZ & 0.105 & 0.887 & 11,783 & $\$ 1,237$ & $\$ 35,530$ & 29 \\
\hline
\end{tabular}

The simple payback for the case of Honolulu, $\mathrm{HI}$ with the federal tax credit is 13 years and the Daggett CA also showed a payback under 20 years in this case.

As the first large-scale installation of this specific PV-T technology, a primary motivation for the project was to outline the design details that need to be addressed in future installations. Future PVT installations should focus on sites that meet all of the following requirements:

- Limited Roof Space - Facilities with limited roof space relative to the size of the electrical and thermal load that are looking to fill the entire roof with solar and maximize solar energy production should be targeted. These facilities are ideal candidates for PVT as more energy can be produced from the same footprint than a separate PV and solar thermal system. 
- High Energy Costs - The natural gas industry has experienced significant cost reductions over the last few years. The economics of the solar thermal system is sensitive to fuel source costs and the cost of electricity on a $\$ / M M B t u$ basis is seven times higher than natural gas in Boston MA. In addition the modeling analysis showed that $\mathrm{HI}$ was the only location where the system was cost effective without federal incentives. For installations where the federal tax credit cannot be captured sites with electric rates of 30 cents/kWh or higher should be targeted, and for systems that can capture the federal tax incentives sites with electric rates of 15 to 20 cents/kWh or higher should be targeted.

- Hot Climates - PV-T systems were shown to have the best economics in warmer locations such as Phoenix AZ, Dagget CA, and Honolulu HI. A PV-T system will produce more hot water on an annual basis in these locations which increases the thermal energy savings. PVT systems were also shown to provide additional PV panel cooling benefits in hot locations since the panel temperatures are hotter in these locations and the impact on increased electrical production has a bigger impact on the overall economics. Systems with both hot climates and high utility rates should be targeted for future installations.

- Central Hot Water Systems - Facilities with centralized domestic hot water systems should be targeted for for PV-T technology and the baseline DHW load should be metered before designing a solar thermal system to size the system properly. Facilities with small decentralized point of use domestic hot water systems are not applicable for solar thermal installations

- Piping Costs - Piping costs need to be considered in future installations. The length of the home run and overall piping costs should as short as possible to minimize installation costs.

In addition to the specific requirements a number of general solar thermal design best practices and lessons learned are outlined below:

- Implement efficiency first - The existing DHW equipment should be analyzed prior to the installation of a SHW system. All applicable water conservation and energy efficiency opportunities should be implemented before sizing a solar thermal system.

- Use accurate component and system design tools to optimize performance - PV-T is a relatively new technology and design tools are still in development to model the solar thermal system and effects on the PV system. For future designs, a detailed hourly analysis should be conducted with SRCC-rated solar thermal panel performance data. This will aid in the correct sizing of the system and enable a more accurate economic analysis.

- Design systems with the same unit flow rate $\left(\mathrm{gpm} / \mathrm{ft}^{2}\right)$ at which the panels were tested - The flow rates through each solar thermal panel should be set to SRCC test conditions, which in this case was a $0.0281 \mathrm{gpm} / \mathrm{ft}^{2}$ collector area.

- Carefully select heat exchangers - The solar thermal heat exchangers between the collection loops and storage tanks should be properly sized to avoid an adverse impact on system performance. The thermal tanks should be sized appropriately based on the solar thermal fraction, design inlet temperature, outlet temperature, and flow rates. 
- Install sub metering - Sub metering should be installed and used to report thermal energy production and compare it to predicted energy production on a monthly basis.

\section{E. Barriers and Enablers to Adoption}

The two primary barriers to market adoption within the GSA building stock consist of the installed costs of the PV and solar thermal system and the magnitude and consistency of the DHW load. Given that the system is less than half as efficient as traditional solar thermal systems, a larger solar thermal system is needed to meet a given solar thermal load, and the installed costs of this specific PV-T system need to be $30 \%$ to $50 \%$ lower than a traditional solar thermal system sized to meet the same loads.

Facilities with electric resistance back-up heating systems should be targeted for future installations and systems with natural gas back up should be avoided unless the local utility incentives can overcome the reduced fuel costs. In the future, the site should require the use of a third-party energy analyst to analyze the economics of a standard PV and standard solar thermal system against the PV-T system using an hourly analysis tool such as TRNSYS. Given that most GSA facilities have intermittent DHW loads and are typically heated with natural gas, a large portion of the GSA building stock may not fit the criteria required for a cost-effective solar thermal project.

Federal and utility rebates that can pay for as much as $75 \%$ of the installed costs of PV and solar thermal system and locations with both PV and solar thermal incentives should be targeted for PV-T installations.

\section{F. Market Potential within the GSA Portfolio}

The majority of the existing buildings in the GSA building stock have relatively small DHW loads and are primarily heated with natural gas. These buildings may not be appropriate candidates for PV-T technology unless significant solar thermal incentives are available. The facilities that should be targeted for PV-T technology are smaller facilities with larger DHW loads. The larger the array, the more challenging it is for the solar thermal design engineer to design a system with the correct flow rate per panel. However, if roof space is limited and there are smaller hot water loads, PV-T could still be a viable solution using fewer thermal panels, provided that the thermal component is properly sized.

In assessing the effect of PV panel cooling, NREL found a larger benefit in the hotter climates with a better solar resource, such as Phoenix AZ, Daggett CA, and Honolulu HI. Facilities that are roof constrained in these locations should be targeted for future installations.

Because EISA 2007 requires that 30\% of the hot water demand in new federal buildings (and major renovations) be met with SHW equipment (provided it is life-cycle cost-effective), new construction and major renovation should be a target market for the technology.

\section{G. Recommendations for Installation, Commissioning, Training and Change Management}

Before installing a PV-T system, the site should install temporary metering on the DHW system to accurately capture the daily hot water usage and load profile. This information is critical to sizing the system correctly. In addition, all of the lessons learned and best practices should be incorporated into future designs that will be life-cycle cost-effective. The operation and maintenance costs are similar to traditional PV and solar thermal technologies and the design and integration of the technology also follows the same general procedures. 


\section{Appendices}

\section{A. Detailed Technology Specification}

A copy of the SRCC test results are provided in Figure 24.

\begin{tabular}{|c|c|c|}
\hline SOLAR COLLECTOR & \multicolumn{2}{|c|}{ CERTIFIED SOLAR COLLECTOR } \\
\hline OG-100 CERTIFIED & $\begin{array}{l}\text { SUPPLIER: } \\
\text { MODEL: } \\
\text { COLLECTOR TYPE: } \\
\text { CERTIFICATION\#: } \\
\text { Original Certification Date: }\end{array}$ & $\begin{array}{l}\text { SunDrum Solar, LLC } \\
15 \text { Hillside Road } \\
\text { Northborough, MA } 01532 \text { USA } \\
\text { SunDrum SDM } 100 \\
\text { Unglazed Flat-Plate } \\
\text { 2007044A } \\
\text { 02-APR-12 }\end{array}$ \\
\hline
\end{tabular}

\begin{tabular}{|c|c|c|c|c|c|c|c|}
\hline \multicolumn{8}{|c|}{ ALL SIZES OF THIS COLLECTOR MODEL ARE CERTIFIED } \\
\hline \multicolumn{8}{|c|}{ COLLECTOR THERMAL PERFORMANCE RATING } \\
\hline \multicolumn{4}{|c|}{ "Kilowatt-hours Per Square Meter Per Day } & \multicolumn{4}{|c|}{ Thousands of BTU Per Square Foot Per Day } \\
\hline \begin{tabular}{|c|} 
CATEGORY \\
(Ti-Ta)
\end{tabular} & $\begin{array}{c}\text { CLEAR } \\
\text { DAY } \\
(6.3 \mathrm{kWh} / \\
\mathrm{m}^{2} \text {.day) }\end{array}$ & $\begin{array}{c}\text { MILDLY } \\
\text { CLOUDY } \\
(4.7 \mathrm{kWh} / \\
\left.\mathrm{m}^{2} \text {.day }\right)\end{array}$ & $\begin{array}{c}\text { CLOUDY } \\
\text { DAY } \\
(3.1 \mathrm{kWh} / \\
\left.\mathrm{m}^{2} \text {.day }\right)\end{array}$ & \begin{tabular}{|c|} 
CATEGORY \\
(Ti-Ta)
\end{tabular} & $\begin{array}{c}\text { CLEAR } \\
\text { DAY } \\
\text { (2000 Btu / } \\
\mathrm{ft}^{2} \text {.day) }\end{array}$ & $\begin{array}{c}\text { MILDLY } \\
\text { CLOUDY } \\
\text { (1500 Btu } / \\
\mathrm{ft}^{2} \text {.day) }\end{array}$ & $\begin{array}{c}\text { CLOUDY } \\
\text { DAY } \\
(1000 \mathrm{Btu} / \\
\mathrm{ft}^{2} \text {.day) }\end{array}$ \\
\hline A $\left(-5^{\circ} \mathrm{C}\right)$ & 2.5 & 2.0 & 1.4 & A $\left(-9^{\circ} \mathrm{F}\right)$ & 0.8 & 0.6 & 0.4 \\
\hline B $\left(5^{\circ} \mathrm{C}\right)$ & 1.5 & 1.0 & 0.4 & B $\left(9^{\circ} \mathrm{F}\right)$ & 0.5 & 0.3 & 0.1 \\
\hline $\begin{array}{ll}\mathrm{C} & \left(20^{\circ} \mathrm{C}\right) \\
\end{array}$ & 0.3 & 0.0 & 0.0 & $\begin{array}{ll}\mathrm{C} & \left(36^{\circ} \mathrm{F}\right) \\
\end{array}$ & 0.1 & 0.0 & 0.0 \\
\hline D $\left(50^{\circ} \mathrm{C}\right)$ & 0.0 & 0.0 & 0.0 & $\mathrm{D} \quad\left(90^{\circ} \mathrm{F}\right)$ & 0.0 & 0.0 & 0 \\
\hline $\mathrm{E} \quad\left(80^{\circ} \mathrm{C}\right)$ & 0.0 & 0.0 & 0.0 & E $\left(144^{\circ} \mathrm{F}\right)$ & 0.0 & 0.0 & 0.0 \\
\hline
\end{tabular}

A- Pool Heating (Warm Climate) B- Pool Heating (Cool Climate) C- Water Heating (Warm Climate) D- Water Heating (Cool Climate) E- Air Conditioning

\begin{tabular}{|c|c|c|c|}
\hline \multicolumn{4}{|c|}{ OLLECTOR SPECIFICATIONS } \\
\hline Gross Area: & $1.570 \mathrm{~m}^{2}$ & $16.90 \mathrm{ft}^{2}$ & Net Aperture Area: $1.57 \mathrm{~m}^{2} 16.90 \mathrm{ft}^{2}$ \\
\hline Dry Weight: & $31.2 \mathrm{~kg}$ & 69. Ib & Fluid Capacity: \\
\hline Test Pressure: & 428. $\mathrm{KPa}$ & 62. psig & \\
\hline
\end{tabular}

COLLECTOR MATERIALS

Frame:

Aluminum

Cover (Outer): $\quad$ Evergreen Spruce PV Module

Cover (Inner): Aluminum

\begin{tabular}{|c|c|c|c|}
\hline \multicolumn{2}{|c|}{ Flow } & \multicolumn{2}{c|}{$\Delta \mathrm{P}$} \\
\hline $\mathrm{ml} / \mathrm{s}$ & $\mathrm{gpm}$ & $\mathrm{Pa}$ & in $\mathrm{H}_{2} \mathrm{O}$ \\
\hline 150.00 & 2.38 & 8947.10 & 35.96 \\
\hline 250.00 & 3.96 & 21887.8 & 88.0 \\
\hline 350.00 & 5.55 & 40406.50 & 162.39 \\
\hline
\end{tabular}

Absorber Material: Tube - Anodized Aluminum I

Plate - Aluminum

Insulation Side: $\quad$ Foam

Absorber Coating:

Evergreen Spruce PV Module

Insulation Back: Foam

TECHNICAL INFORMATION

Efficiency Equation [NOTE: Based on gross area and $(\mathrm{P})=\mathrm{Ti}-\mathrm{T}$
SI Units:
$\eta=0.334$
-18.40950 (P)Л
$0.39213(\mathrm{P})^{2} / 1$
IP Units:
$\eta=0.334$
-3.24283 (P)/
$0.03837(\mathrm{P})^{2} /$

Y INTERCEPT

Incident Angle Modifier [(S)=1/cos $\left.\theta-1,0^{\circ}<\theta<=60^{\circ}\right]$

Кт $\alpha=1 \quad 0.962$ (S) $\quad-0.641(\mathrm{~S})^{2}$

$\mathrm{KT \alpha}=1 \quad 0.29(\mathrm{~S})$

Linear Fit

Test Fluid:

Test Flow Rate:

$0.336-1.952 \mathrm{Btu} / \mathrm{hr} . \mathrm{ft}^{2}{ }^{\circ}{ }^{\circ} \mathrm{F}$

Equations listed above are based on only the low wind speed data from a test conducted in accordance with ISO 9806-3. When all data is included: Efficiency $=0.3372-0.0255^{\star} u-(10.1245-$ $\left.0.24453^{*} u\right)^{*}(P) / G^{\prime \prime}$. PV electrical contacts were open during testing.

April, 2012

Certification must be renewed annually, For current status contact SOLAR RATING \& CERTIFICATION CORPORATION

400 High Point Drive, Suite 400 • Cocoa, Florida 32926 • (321) 213-6037 • Fax (321) 821-0910

Figure 24. SunDrum SRCC rating 


\section{B. Glossary}

\begin{tabular}{|c|c|}
\hline$A C$ & Alternating current \\
\hline ARRA & American Recovery and Reinvestment Act of 2009 \\
\hline CdTe & Cadmium Telluride \\
\hline CIGS & Copper Indium Gallium Diselenide \\
\hline DAS & Data acquisition system \\
\hline DC & Direct current \\
\hline DHW & Domestic hot water \\
\hline DOE & Department of Energy \\
\hline EIA & Energy Information Administration \\
\hline EISA & Energy Independence and Security Act of 2007 \\
\hline EPAct & Energy Policy Act of 2005 \\
\hline FSEC & Florida Solar Energy Center \\
\hline GHG & Greenhouse gas \\
\hline GPD & Gallons per day \\
\hline GPM & Gallons per minute \\
\hline GPG & Green Proving Ground program \\
\hline GSA & General Services Administration \\
\hline GW & Gigawatts \\
\hline$H x$ & Heat exchanger \\
\hline IAM & Incident angle modifier \\
\hline kBtu & Thousand British thermal units \\
\hline $\mathrm{kW}$ & Kilowatt \\
\hline$M \& V$ & Measurement and verification \\
\hline MMBtu & Million British thermal units \\
\hline MW & Megawatt \\
\hline MWh & Megawatt hour \\
\hline NREL & National Renewable Energy Laboratory \\
\hline PV & Photovoltaic \\
\hline PV-T & Photovoltaic - thermal \\
\hline $\mathrm{RE}$ & Renewable energy \\
\hline$R \& D$ & Research and development \\
\hline SAM & Solar advisor model \\
\hline
\end{tabular}




$\begin{array}{ll}\text { Si } & \text { Silicon } \\ \text { SHW } & \text { Solar hot water } \\ \text { SRCC } & \text { Solar Rating and Certification Company } \\ \text { TMY } & \text { Typical Meteorological Year } \\ \text { TRNSYS } & \text { Transient System Simulation Tool } \\ \text { VOC } & \text { volatile organic compound } \\ \text { W } & \text { Watt }\end{array}$

